\title{
An Unstoppable Tide: Creating Environmental and Human Rights Law from the Bottom Up
}

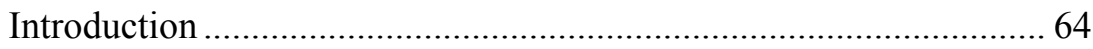

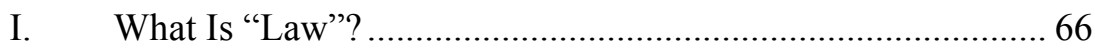

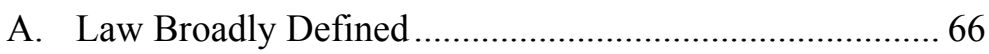

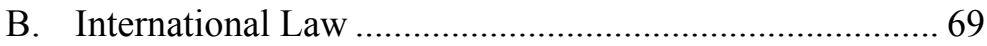

C. "International Law": A Universalist or Narcissistic

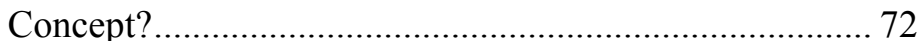

D. "National" or "International" Law: Does it Matter? ........ 74

II How Law Is Created .............................................................. 77

A. Top-down Lawmaking ................................................ 77

B. "Bottom-up" Lawmaking:.............................................. 80

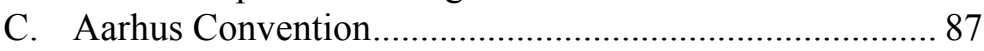

III. Why Law Is Observed .......................................................... 89

IV. The Intersection Between Human Rights and

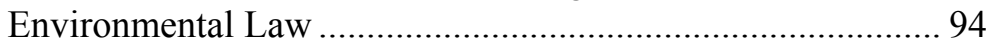

V. A Tale of Five Cities: Bottom-up, Polycentric Approaches

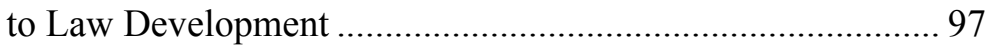

A. San Francisco Human Rights Law: International Inspiration Leads to Local Action ..................................... 97

B. Human Rights Law in New York City: An Enforcement-based Model ...

\footnotetext{
* Myanna Dellinger, J.D. (Coif), M.A., is an Assistant Professor of Law with Western State College of Law in California. She dedicates this Article to the memory of Dr. Svitlana Kravchenko, a pioneer within human rights and the environment as well as a good friend and role model. Professor Dellinger is grateful to Professor John Bonine for his continued professional support of Professor Dellinger, as well as to the University of Oregon School of Law for the chance to present this Article at the symposium New Directions for Human Rights and the Environment. Professor Dellinger is further grateful to Professor Jennifer Koh of Western State College of Law for providing inspiration for this Article and the Western State College of Law for summer research funds for this project.
} 
C. Climate Change in New York City: Modeling Local Authority on International Initiatives ............................. 110

D. Denver: Practical Lessons in Public Participation ......... 112

E. Santa Fe: Interweaving Sustainability with Principles of Economic Health and Social Justice .......................... 118

F. London: New Frameworks for Climate Change and Public Participation ....................................................... 120

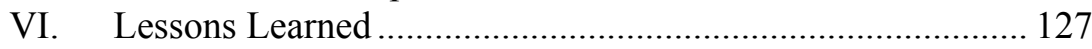

A. Development of the Law ............................................. 128

B. Substantive Contents in Legal Developments................ 133

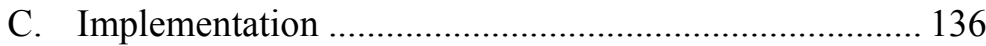

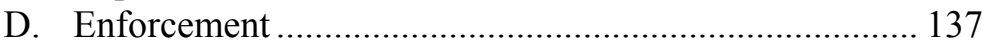

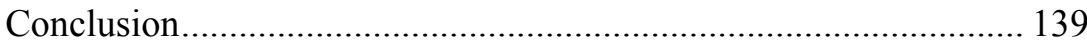

\section{INTRODUCTION}

Around the world, numerous attempts have been made to solve difficult, yet pressing issues within human rights and environmental law. Many have fallen short, some even at times when they wereand still are-needed the most. But despite this bleak background, there is yet hope: persistent and innovative legal thinking at the subnational level has created new action in areas previously marked by relative or near-complete inaction on the part of national governments and supranational organizations. Civil society and local governments can, by taking note of such developments, gain more insight into how to move their agenda forward through new channels. Time has come for local actors and civil society to stop looking to large-scale action that may or may not come about in a timely fashion. This Article proposes that bottom-up, polycentric developments within national and international environmental and human rights law present viable and strong alternatives to traditional top-down solutions, especially in relation to problems that require urgent legal action. The Article does not, however, suggest that traditional solutions are no longer called for. Rather, it promotes action from both angles.

The Article starts by analyzing the notion of "law" in order to demonstrate that law does not only consist of formal positive law, but also comprises broader concepts of a universally accepted nature, whether or not officially adopted by governments. This section will additionally explore what "international law" means in an American context and briefly discuss whether our concept of law is, in general, unnecessarily limited to Western ideals. The purpose of the section is to demonstrate that many of the notions that form part of the 
discourse in both environmental and human rights law-whether seen as separate or intertwined issues - such as what is "right" and "wrong," already form part of a wider view of the notion of law itself. An awareness of this can be used in promoting the incorporation of such aspects into formal law.

The Article proceeds to examine the two major methods of lawmaking: top-down or bottom-up solutions. The main advantages and disadvantages of each will be briefly analyzed in order to demonstrate the many recognized advantages of bottom-up law creation to law-and-policy-makers and stakeholders at the local and non-local scales. This will support the theory of the Article, namely that lawmaking involving local actors and civil society is unavoidable, and that this a boon to society.

The Article then briefly describes why law is observed at all. ${ }^{1}$ Advocates for change in the human rights and environmental law fields can rely upon this insight in framing arguments for broader legal or quasi-legal protections of our human and natural environments.

This introductory material will serve as a framework of reference for the argument that if we take new approaches to both the creation and enforcement of law, valuable and urgently needed legal and other social progress can be created in shorter timeframes than if waiting for more sluggish national and supranational action. After explaining how human rights and the environment can be seen as separate or merged disciplines, it will become apparent that even where they are separate, lessons learned in one will typically be applicable in the other as well. The specific lessons presented in this Article will be drawn from experiments with localized action in four select cities across the United States and one in the EU. Some of the experiments relate only to human rights, others only to environmental issues. The lessons are, of course, also valuable to those instances in which environmental issues are seen as human rights issues and to a broader range of situations where bottom-up lawmaking may prove expedient.

Many scholarly articles have debated the need for alternatives to traditional top-down lawmaking. This Article builds on such scholarship and creates new value in two ways. First, the original research for this Article analyzes select examples of bottom-up

1 However, the Article does not consider any court resolutions to the substantive problems at issue because the main purpose of the Article is to analyze the development of law rather than the enforcement thereof. 
lawmaking to examine the on-the-ground implementation of the theory and to identify those aspects thereof that appear the most illustrative of lessons that can be repeated as well as pitfalls to avoid. Second, the Article produces new value in setting forth guidelines for legal practitioners and scholars seeking to further promote and apply the development of law at the bottom-up, polycentric level. The Article will also serve as the launching point for the author's parallel project, which more narrowly examines whether pursuing climate change action at the sub-national, sub-state level with or without government interaction is successful and how "success" can be measured in relation to climate change in particular. ${ }^{2}$

\section{I}

\section{WHAT IS “LAW"?}

In order to understand how human rights law and environmental law may develop from multiple angles, it helps to initially consider the spectrum of what may be said to constitute "the law." However, as the purpose of this Article is to shed light on some practical and current ways of developing new law, the Article purposefully will not provide a full socio-philosophical description of the notion of law. Rather, this section is meant to provide only a broad framework for later reference in this Article and for possible use by civil society and government practitioners and policymakers. The section starts from a general perspective and then hones in on international law.

\section{A. Law Broadly Defined}

We typically think of "law" as common law and codes, statutes, and regulations traditionally applied and enforced in courts of law, in other words that which is known as formal or "positive law."3 This definition encompasses " $[\mathrm{t}]$ he regime that orders human activities and

2 Myanna Dellinger, Localizing the Law of Climate Change, 14 MinN. J. L. SCI. \& TECH. (forthcoming 2013).

3 See, e.g., BLACK's LAW Dictionary 1280 (9th ed. 2009) (“A system of law promulgated and implemented within a particular political community by political superiors, as distinct from moral law or law existing in an ideal community or in some nonpolitical community. Positive law typically consists of enacted law-the codes, statutes, and regulations that are applied and enforced in the courts. The term derives from the medieval use of positum (Latin 'established'), so that the phrase positive law literally means law established by human authority."). Positive law "only considers law flowing down from the sovereign as true law" and may thus be said to be "manufactured" law. Prabhakar Singh, From 'Narcissistic' Positive International Law to 'Universal' Natural International Law: The Dialectics of 'Absentee Colonialism,' 16 AFR. J. INT’L \& COMP. L. 56, 59 (2008). 
relations through systematic application of the force of politically organized society, or through social pressure, backed by force, in such a society." relatively "soft" normative concept—social pressure-may actually take on some force, but only if enforced by societal institutions such as courts of law. Whereas experts taking the traditional view of law may question the notion that untraditional, softer concepts have much legal relevance, others take quite another stance on this issue:

Some twenty years ago I pointed out two ideas running through definitions of law: one an imperative idea, an idea of a rule laid down by the lawmaking organ of a politically organized society, deriving its force from the authority of the sovereign; and the other a rational or ethical idea, an idea of a rule of right and justice deriving its authority from its intrinsic reasonableness or conformity to ideals of right and merely recognized, not made, by the sovereign. ${ }^{5}$

The notion that law does not only consist of positive law is further supported by the theory applying to natural law, also known as "lex naturalis." Natural law is a theory of jurisprudence that contends that law has its origin and justification in absolute standards of right and wrong. ${ }^{6}$ It thus encompasses a broader notion that "law" may also be seen as behavioral, ethical, or social norms; ${ }^{7}$ in other words, as "universal principles of morality and justice." In the 1960s, a group of scholars developed the sub-concept of "new natural law." In spite of its name, this theory takes a mainly conservative, preEnlightenment view of the law as it relates to, for example, issues of homosexuality, marriage, and contraception. ${ }^{10}$ New natural law adherents argue that "there are moral absolutes, that is, norms that specify certain acts as of a sort that are always and everywhere not to be done." $"$ To distinguish the two belief systems, the phrase

\footnotetext{
4 BLACK's LAW DICTIONARY, supra note 3, at 962 (emphasis added).

5 Roscoe Pound, More About the Nature of Law, in LEgAL ESSAYS IN TRIBUTE TO ORRIN KIP MCMURRAY 513, 515 (1935) (emphasis added).

6 Moore v. Ganim, 660 A.2d 742 (Conn. 1995). See also William P. Aspell, Natural Law in the Connecticut Tradition, 31 ConN. B.J. 105 (1957).

7 Mohammed v. State, 561 So.2d 384, 385 (Fla. Dist. Ct. App. 1990).

8 Singh, supra note 3 , at 57.

9 Christopher Tollefsen, The New Natural Law Theory, 10 LyCEUM 1 (2008), available at http://lyceumphilosophy.com/?q=node/97.

$10 \mathrm{Id}$.

11 Id. at 6 .
} 
"traditional natural law" or just "natural law" will in the following be used for the opposite of "new natural law."

Traditional and new natural law relate closely to the human rights and environmental law discourse. As for environmental law, the question has been raised whether traditional natural law supports taking an ecocentric view to environmental law or whether the purpose of such law should, more narrowly, be considered to only be to support human existence. Traditional natural law took the starting point that human "goods" such as life, knowledge, friendship, practical reason, play, religion, and aesthetic experience were mainly pursued for anthropocentric reasons. ${ }^{12}$ Thus, an ecocentric approach to environmental protection was only sometimes seen as justified. ${ }^{13}$ Action was considered to be taken to benefit humankind, not the environment per se. ${ }^{14}$ Modernly, however, "actions can be taken for ethical and thus natural law reasons simply because they are 'good,' albeit not necessarily 'good for' human beings. ${ }^{15}$ For example, endangered species may be preserved out of a realization that the planet and its future generations of humans and non-humans will be better off for doing so. Another example is the concept that farm animals can be slaughtered in less painful ways than before simply because we now know how to do so, but also because our capacities have evolved experientially and developmentally, so although something is said to be purely natural (killing animals) for us, other entities also have ends that may sometimes have a value that is worth pursuing for its own sake. Thus, traditional natural law also supports ecocentric action for our sake although benefit to human goods is only indirect. ${ }^{16}$

New natural law, in contrast, "[does] not afford the opportunity to ask whether there can be a reason for human action that is not connected to what is good for human beings."17 In other words, whereas new natural law supports environmental protection, it does so only for anthropogenic reasons so long as human goods are at issue. ${ }^{18}$ Nonetheless, new natural law and environmental action can go hand

12 Bebhinn Donnelly \& Patrick Bishop, Natural Law and Ecocentrism, 19 J. ENVTL. L. 89, 92 (2007).

13 Id. at 90.

14 Id.

15 Id. at 94.

16 Id. at 101 . Donnelly does not take a stance on whether or not it is morally sound for human beings to consume animals or slaughter them for other human purposes.

17 Id. at 93.

18 Id. at 94. 
in hand. For example, the basic human good of life is often the rationale behind environmental protection in general and would thus be supported under the new natural law school of thought as well. ${ }^{19}$ Similarly, urban and rural planning schemes can be analyzed in terms of furthering the basic good of aesthetic experience. ${ }^{20}$ The United States federal government has recognized the need for a clean, healthy environment as a prerequisite for the fostering of good societal relations just as the regime contained in the United States Wildlife and Countryside Act of 1981 - which allows for the creation of Sites of Special Scientific Interest, National Nature Reserves and Marine Nature Reserves - references the human good of knowledge. ${ }^{21}$ And since human goods are the fundamental concern of the human rights discourse, new natural law supports a strong rationale for human rights legislation as well.

Thus, whereas "new" and "traditional" natural law may differ greatly in some areas of the law that are currently the subject of much debate in the United States, the two theories converge in lending support to legal progress within environmental law, albeit the reasons for doing so differ. Finally, "[t]o maintain order and promote productivity, modern societies rely not only on formal law, but also on complex webs of nonlegal rules, including workplace rules, religious rules, ethical rules, and the community 'rules' of polite and cooperative behavior that [are known as] 'social norms.",22

\section{B. International Law}

A brief review of the components of international law is useful in remembering the full panorama of that which constitutes "law" and how it is created.

Article 38.1 of the Statute of the International Court of Justice (ICJ or the Court) identifies the three primary sources of international law as treaties, "international customs" (more commonly known as customary international law), and "general principles of law." Treaties are simply legally binding agreements between two or more states. ${ }^{23}$ Customary international law contains two elements: (1)

\footnotetext{
19 Id.

20 Id. at 95.

21 Id. at 94.

22 Lynn Stout, Cultivating Conscience: How Good Laws Make Good People 237 (2011).

23 Vienna Convention on the Law of Treaties art. 2(1)(a), May 23, 1969, 155 U.N.T.S. 331.
} 
general practice that (2) is accepted as law. ${ }^{24}$ In turn, "general practice" contains two sub-elements: "general" and "practice." Not all nation states need to follow a practice for it to be "general," but it must be followed by most states, especially those affected by the custom. ${ }^{25}$ States who "persistently object" to the practice during the process of its formation will not be bound to it. ${ }^{26}$ Examples of "practice" are diplomatic acts and instructions, public measures, other governmental acts, and official statements of policy, whether unilateral or not. ${ }^{27}$ Practice is thus broadly evidenced by internal legal states of affairs such as domestic legislation, judicial decisions, internal government memoranda, ministerial statements, ${ }^{28}$ diplomatic correspondence, press releases, or opinions of legal advisers. In contrast, the question of whether failures to act fall under the "practice" umbrella is open to debate. ${ }^{29}$ For something to be "accepted as law," it must constitute opinio juris:

[I]n order to achieve this result, two conditions must be fulfilled. Not only must the acts concerned amount to a settled practice [the "objective element"], but they must also be such, or be carried out in such a way, as to be evidence of a belief that this practice is rendered obligatory by the existence of a rule of law requiring it. The need for such a belief, i.e., the existence of a subjective element, is implicit in the very notion of the opinio juris sive necessitatis. The States concerned must therefore feel that they are conforming to what amounts to a legal obligation. ${ }^{30}$

In other words, opinio juris ${ }^{31}$ correlates to a practice followed by nation states out of a sense of legal obligation as opposed to mere

24 Statute of the International Court of Justice art. 38(1)(b), June 26, 1945, 59 Stat. 1055

25 North Sea Continental Shelf (Ger./Den., Ger./Neth.), Judgment \& Dissenting Opinion of Judge Lachs, 1969 I.C.J. 3, 42, 43, 218,229 (Feb. 20) [hereinafter North Sea Continental Shelf]; Military and Paramilitary Activities (Nicar. v. U.S.), 1986 I.C.J. 14, 98 (June 27).

26 STEPHEN C. MCCAFFREY, UNDERSTANDING INTERNATIONAL LAW 46 (2006).

27 RESTATEMENT (THIRD) OF THE FOREIGN RELATIONS LAW OF THE UNITED STATES $§$ 102 (1988).

28 MCCAFFREY supra note 26, at 48.

29 See, e.g., S.S. "Lotus” (Fr. v. Turk.), 1927 P.C.I.J. (ser. A) No. 10 (Sept. 7).

30 North Sea Continental Shelf, supra note 25, at 44.

31 A recent example of opinio juris can be found in a White House press release by the Obama administration stating about Article 75 of Additional Protocol I to the 1949 Geneva Convention, which sets forth fundamental guarantees for persons in the hands of opposing forces in an international armed conflict, that "[a]lthough the Administration continues to have significant concerns with Additional Protocol I, Article 75 is a provision of the treaty that is consistent with our current policies and practice and is one that the United States has historically supported . . The U.S. Government will therefore choose out of a sense of 
protocol, habitual character, courtesy, convenience, or tradition. ${ }^{32}$ States consistently objecting to international practices, declarations, statements, or resolutions that may otherwise be said to signify the existence of a rule of customary international law will not be held to such a rule. ${ }^{33}$

Although customary international law has no precise counterpart at the domestic level in the United States, rough equivalents could be considered to be unwritten trade usage and custom in commercial law; the common law system itself, which was customary in nature before the courts began to write it down; or even social norms and etiquette. $^{34}$

General principles of law are those that are derived purely from the national law of the major legal systems of the world. ${ }^{35}$ They can be established by both legislatures and courts. ${ }^{36}$ In other words, general principles of law may be considered "gap fillers" in the international legal system if such principles are common to many systems of law.

Jus cogens is a peremptory norm agreed upon by the international community as one from which a derogation may never occur because of fundamental concerns of ethics and thus also falls under international law. Examples of jus cogens are the prohibition against genocide, slavery, wars of pure aggression, and the recognition of territorial sovereignty. ${ }^{37}$ Finally, international law may also draw upon the teachings of "the most highly qualified publicists of the

\footnotetext{
legal obligation to treat the principles set forth in Article 75 as applicable to any individual it detains in an international armed conflict, and expects all other nations to adhere to these principles as well." Press Release, White House, Fact Sheet: New Actions on Guantanamo and Detainee Policy (Mar. 7, 2011), available at http:/www.lawfareblog.com/wp-content /uploads/2011/03/Fact_Sheet_-_Guantanamo_and_Detainee_Policy.pdf.

32 North Sea Continental Shelf, supra note 25, at 44.

33 Legality of the Threat or Use of Nuclear Weapons, Advisory Opinion, 1996 I.C.J. 226, ๆ 68 (July 8).

34 MCCAFFREY, supra note 26, at 44.

35 Restatement (ThiRd) OF THE Foreign RELATIONS LAW OF THE UNited STATES $\S$ 102(1)(c).

36 MCCAFFREY, supra note 26, at 56.

37 See, e.g., East Timor (Port. v. Austl.), Judgment, 1995 I.C.J. 102 (June 30). Compare "jus gentium"- a form of natural law considered by some jurists to be innate in every human being; a higher law of moral obligation binding human beings beyond the requirements of civil law. See generally MARCUS TUllius CiCERO, DE OfFICIIS 3.17.69;

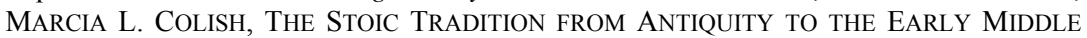
AGES 150 (1985).
} 
various nations." 38 Although the Trail Smelter arbitration case drew upon this source, ${ }^{39}$ doing so is relatively rare.

Thus, just as the notion of law seen from a national point of view can cover other sources than positive law, so can international law. In fact, only treaties truly match the definition of positive law, as only they are formally adopted by governments in relation to action at the international level. The other sources - customary international law, general principles, jus cogens, and writings by eminent scholars - are drawn upon in their looser forms as gap-fillers, norms, and tradition, also not formal sources of law seen from a traditional point of view. Thus, actors developing law either at the international level or in relation to issues of international significance are already no strangers to encompassing "softer" concepts of law, which is positive in relation to further developments of human rights and environmental law.

The above considerations are most often discussed in connection with "public international law," which refers to controversies or conduct between nation states. "Private international law" refers to conflict of laws and the choice of applicable law in private disputes involving more than one jurisdiction. ${ }^{41}$

\section{C. "International Law": A Universalist or Narcissistic Concept?}

Historically, "international" law developed from a Eurocentric angle in a highly colonized world. Natural law, which truly applies universally for the above-mentioned reasons, was dismissed in order to promote a type of international law that could justify colonialism. ${ }^{42}$ Accordingly, the Western world and the "East" or "Global South" became divided between not only the colonizers and the colonized in general, but also on sharp cultural lines within notions of what constitutes law to begin with. ${ }^{43}$ "International law" scholarship declared itself superior to all that was non-European. ${ }^{44}$ Other belief systems were, at bottom, considered to be unable to present any case for equality of treatment under international law. ${ }^{45}$ This false

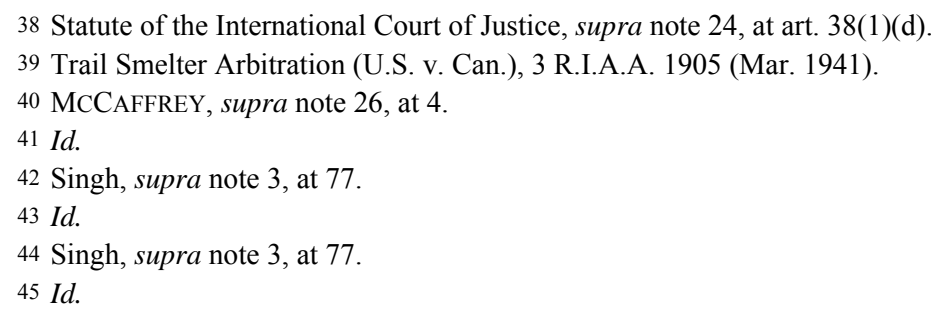



and Human Rights Law from the Bottom Up

universality system justified interference in the "uncivilized world" by "civilized nations" that considered themselves culturally, and thus legally, superior. ${ }^{46}$ To a large extent, this is arguably still the case. The existing Western legal belief system has thus been called "narcissistic.",47

In the meantime, the Global South has emerged as a vibrant sociopolitical actor. Hence, non-Western notions of what constitutes international law should be included in the international legal vocabulary $^{48}$ as well in order to obtain a more universally acceptable view of international law. Modernly, there can be true universality of "international law" only if it does not discriminate between, for example, Asian, African, or European systems of law. ${ }^{49}$ But it still does. However, after the addition to the International Court of Justice of non-European judges, the Court has, for example, started respecting the "natural law" aspect of international law, particularly in judgments and advisory opinions delivered by third world judges. ${ }^{50}$ For example, the former Vice President of the ICJ, Justice Christopher Gregory Weeramantry of Sri Lanka, has stated that international law suffers from the "neglect of other cultures. ... [It is] largely a monocultural construct . . . ; there was also a neglect of the .. . natural law background from which international law had its beginnings. ${ }^{, 51}$ Modernly, international law is increasingly seen to also include ancient tenets of law offered by Hinduism, Buddhism, and Islam $^{52}$ as parallel, but of course not inferior, value systems. Thus, in an advisory opinion on the legality of nuclear weapons, Justice Weeramantry cited to specific teachings from Hinduism about the prohibition of hyper-destructive weapons. ${ }^{53}$

$46 I d$.

47 See, e.g., Singh, supra note 3 , at 76.

48 The concepts of "international law" or "international relations" may more correctly, although somewhat provocatively, also be termed "absentee colonialism" after the fall of Western colonization. For terminological scholarship, see, e.g., Singh supra note 3, at 70 ("classic international law is gradually being replaced by a theory of international relations that boasts of a much more sophisticated vocabulary than diplomatic international law.").

49 Singh supra note 3 , at 68 .

50 Id. at 78 .

51 Christopher G. Weeramantry, International Law and the Developing World: A Millennial Analysis, 41 HARV. INT'L L.J. 277, 278 (2000).

52 Singh supra note 3 , at 78 .

53 Legality of the Threat or Use of Nuclear Weapons, supra note 33. 
The development of international law is thus continuing - and must still continue - as a global rather than a purely Western construct. ${ }^{54}$

The problem with traditional international law is that it can be and still is used for various exploitative means and reasons. ${ }^{55}$ For example, postcolonial differentiations are still made based on economy and power. This is not only a problem in the human rights regime, but also in relation to climate change, where developing nations assert their right to develop without having to undertake total greenhouse gas (GHG) emission commitments. The argument is that total emission commitments make it much more difficult for developing nations to enhance their economies and that per capita emissions are preferable. However, industrialized nations rather stubbornly cling to demands of total commitments from developing countries. To a very large extent, this status quo thus ignores or rejects the economic abilities and prospects of developing nations and threatens their very development - a narcissistic attitude indeed. Various kinds of injustices that currently prevail in relation to the Global South need to be addressed by truly reaching and applying a new epistemology of international law as regards the current broad spectrum of economic, cultural, distributive, environmental, and industrial injustice. ${ }^{56}$ Doing so would enable actors at various scales to invent and implement newer solutions to current environmental and human rights concerns. Seeing things from an interrelated and more holistic point of view would appropriately link modern notions of international and national law to traditional notions of natural law and thus make a full circle out of what is currently an inexpediently fragmented system of law. ${ }^{57}$ For "[i]t is in natural law that we can find the tenets that succour human kind, promote universal principles of equality and justice: all that is needed to make international law truly 'international' and not just a 'European' or 'American' construct." 58

\section{D. “National” or “International” Law: Does it Matter?}

Much attention has been paid to the creation and improvement of law through conventional national sources of law, in particular through constitutional and other federal law (in the United States), EU and national law (in Europe), and international treaties at the

\footnotetext{
54 Singh supra note 3 , at 79

55 Id. at 81.

56 Id. at 80.

57 See, e.g., id. at 81.

58 Id. at 81.
} 
supranational level. But as has become evident, these sources are unlikely to create the substantive results that much of civil society is hoping for in many contexts, especially in a timely matter when it comes to pressing issues such as climate change. New ways of thinking are necessary. Similarly, the traditional difference between "international" and other systems of law is losing its significance as national borders and thus "national" law are becoming less and less well-defined both within public and private international law. "Borders are no longer as significant as they once were ... . [T]hey are hardly impenetrable frontiers, but rather flimsy and insubstantial curtains of gauze, through which goods, ideas, and people flow rather easily." 59

Nonetheless, federal and international sovereignty concerns are relevant to both the human rights and environmental law discourse in the United States. Here, federalism and other constitutional concerns abound as soon as the legal significance of any type of border, be it state or federal, is discussed. International readers who may be more accustomed to a perhaps more relaxed view on state borders being an aspect of life that legal society in general and courts in particular can relatively easily maneuver their way around may wish to consider the complexity of the United States federal system and the power struggles that arise here in relation to issues of sovereignty and federalism seen from both an international and a national point of view. ${ }^{60}$ It is - from a broader scholarly perspective — clear that

59 Lawrence M. Friedman, Borders: On the Emerging Sociology of Transnational Law, 32 STAN. J. INT'L L 65, 90 (1996). Unsurprisingly, the popularity of the Internet and the globalization of trade are significant factors in considering why the lines between what was historically a relatively clear demarcation of state, federal and international legal authority blur:

Global trading, national and transnational companies . . the Internet, a population of which 17 percent move annually and of which some 40 percent do not live in the [federal] state of their birth - none of these are easily categorized as belonging to either singularly to one [federal] state or exclusively to the national government.

Judith Resnik, Afterword: Federalism's Options, 14 YALE L. \& POL'Y REV. 465, 482 (1996).

60 The existence of boundary lines between states is a fact of our constitutional life. A central issue of federalism is the significance of these boundaries. Personal jurisdiction doctrine addresses this issue with respect to one feature of our federalist nation, the existence of separate court systems in each of the fifty boundaried areas. It attempts to justify the constitutional limits placed on the adjudicatory authority of each of these court systems over nonresidents. In performing this seemingly narrow task, however, the doctrine necessarily implicates a vision of the nature of American federalism. 
[t]erritoriality and physicality - material connections in water, air, and land-[have traditionally been] centerpieces of jurisdictional authority, theory, and practice . . . . But we who think about courts will need to reassess assumptions - both of structure and of process-heretofore deeply rooted in the physical relationship of human beings on a specific piece of soil and a particular courthouse.

What does this mean to the change called for within human rights and environmental law alike? The answers to this question are outside the scope of this Article, but some of the issues that could be considered in future scholarship and in promoting new legal regimes are whether the concept of "one supreme sovereign" has become of diminished relevance in relation to some substantive areas of law. Scaled-down efforts may be taking over what used to be work more or less exclusively kept within the sovereign realm. To be sure, action at the sovereign level is still important, but it is necessary to continue examining how, if at all, sovereigns can address global problems such as climate change that appear to be too politically laden to be resolved at the macro level. Further, exactly who would be the "sovereign" to take such action - only a national sovereign, or also state, tribal, or indigenous sovereigns? In regards to sources of international law: if more nations adopted climate change legislation, might general principles of law or customary international law be just as effective or even more effective than treaties, to which most of us have looked for solutions so far? The problem with this line of argument is, however, a circular one, at least in the United States: both general principles of law and customary international law require a national sovereign to act, but this is precisely what the United States has so far and so often refused to do in both the climate change and human rights arenas. Perhaps it is time to expand our traditional views of sources of international law to also include action taken at smaller scale by local governments such as cities or regions. After all, effective action can and does spread upward from lower scales and needs to be implemented and enforced at the local level anyway. One thing has become clear: yesterday's traditional thinking does not serve the global community well anymore in those areas of the law that have significant on-the-ground effects. New methods of the creation of law must be considered.

Terry S. Kogan, A Neo-Federalist Tale of Personal Jurisdiction, 63 S. CAL. L. REV. 257, 262-63 (1990).

61 Resnik, supra note 59, at 489. 


\section{II}

\section{HOW LAW IS CREATED}

Law and policy are typically created in one of two ways: by socalled "top-down" or by "bottom-up" approaches. Many people probably think of law as being created only through formal top-down approaches, such as legislatures adopting new laws or judges creating common law. However, alternative and often overlooked avenues exist. These present valuable opportunities for progress where traditional regimes have failed or stalled. This section will set forth the advantages and disadvantages of both types of lawmaking. It posits that both bottom-up models and polycentric models are needed for the most effective and speedy change of law.

\section{A. Top-down Lawmaking}

Seen from a macro level, law is typically, in democratic legal systems, created in the form of statutes by elected legislatures who declare general principles that are to be applied in future situations (i.e., from the "top down"). ${ }^{62}$ Only rarely is legislation adopted to decide specific current disputes. ${ }^{63}$ In common law nations, law is also created when elected or appointed state and federal judges hand down their decisions. In contrast to legislation, such case-by-case adjudication produces law when courts adopt general principles to decide the outcome of individual future disputes. ${ }^{64}$ Top-down lawmaking is thus geared towards the future rather than current solutions. It is also widely considered to be "government driven." Although some judges and experts consider common law to be a bottom-up solution as it derives from individuals-judges-who approach one problem at a time as it arises, ${ }^{65}$ this Article considers common law to be more typical of traditional top-down solutions since a limited range of powerful governmental actors-judgescreate this type of law without the input from civil society otherwise typical of modern bottom-up solutions.

In the traditional top-down approach, international lawmaking typically centers on nation states adopting formal treaties or other binding instruments deriving from treaties. Such law is made by

62 Jeffrey J. Rachlinski, Bottom-up Versus Top-Down Lawmaking, 73 U. CHI. L. REV. 933, 934 (2006)

63 Id. at 933.

64 Id.

65 Id. at 934. 
"elite" actors who are often relatively far removed both politically and geographically from the entire lawmaking process, but whose law is nonetheless imposed on those they govern. ${ }^{66}$

There are many advantages of top-down solutions at both the national and supranational levels. For example, large government bodies typically have many more technical, financial, human, and other resources at their disposal than small actors, budgetary crises notwithstanding. With large resource pools come at least the potential for great competencies and deep expertise. Because of their traditional positions as lawmakers and enforcers, governments also typically enjoy the respect of civil society, at least in positive myth nations (see below). In democratic nations, there is little doubt about the validity of the actions taken at the national and supranational levels. And even if the general public is resentful towards their governments, the latter have powerful compliance methods at their disposal. Of course, the need for large-scale government action is recognized simply because civil society and small-scale actors can only do so much alone; there is quite a bit of natural interdependency between governments and the people they govern.

However, legal change at the national and international levels often comes at a glacial place, if at all. It takes much momentum for nation states to develop new law at the international level and, as is seen with the treaty regime, often quite a bit of compromise as well. Often, otherwise innovative and good legal solutions perish or stall when nations either cannot agree on the fine details of the potential new instruments or refuse to ratify them. Thus, the traditional top-down regime is, for good reason, often considered too cumbersome and too unlikely to produce the desired results in short time. Examples abound of the ineffectiveness in relying exclusively on large-scale action to solve problems of pressing significance. For example, think climate change: the international community of nation states have agreed to make an attempt to hold the increase in global average temperature below $2^{\circ} \mathrm{C}$ above pre-industrial levels. ${ }^{67}$ To do so, GHG

66 Janet Kovin Levit, A Bottom-Up Approach to International Lawmaking: The Tale of Three Trade Finance Instruments, UGA International Law Colloquium 1 (2007), available at http://digitalcommons.law.uga.edu/cgi/viewcontent.cgi?filename $=4 \&$ article $=1011 \&$ context=conf_coll_symp_colloquia\&type=additional ("Top-down international lawmaking stories typically center on a state's treaty-based commitments or an intergovernmental institution born from a treaty, and they tell of state actors making international law and imposing it on others who may have been quite removed, geographically and politically, from the entire lawmaking process.").

67 United Nations EnVIRONMENT Programme, Bridging the EMISSIONS GaP 14 (2011). 
emissions must be reduced drastically and urgently. ${ }^{68}$ Nonetheless, the parties to the UNFCCC most recently-at the December 2012 Doha Conference of the Parties - only agreed to a decision stating the "importance" of adopting a legally binding instrument to replace the Kyoto Protocol by 2015 and indicating that this new treaty should come into effect in $2020{ }^{69}$ In reality, it is far from certain that the international community will be able to agree on a much furtherreaching agreement than the Kyoto Protocol over the course of a few years. In fact, the parties themselves have "noted with grave concern the significant gap between current national and international efforts to reduce emissions and those required by science to ensure a reasonable chance of holding global temperature increases below two or 1.5 degrees Celsius." ${ }^{, 70}$ So whereas "[t]hese observations reflect a clear realization by both Parties and the scientific community that the level of ambition needs to be raised further," that the global consensus on how to do so at the supranational level appears unlikely to come about in the near future, if at all. However, what may at first appear to be a paradox is arguably just simple international legal and socio-political reality, namely that effective climate change action is currently unlikely to result from large-scale action requiring a large number of nations with widely divergent national interests to reach a broadly applicable agreement.

68 For example, the United Nations Environment Programme's BRIDGING THE EMISSIONS GAP report states that to reach the $2^{\circ} \mathrm{C}$ goal, global anthropogenic emissions need to peak before 2020 and be reduced to approximately $44 \mathrm{GtCO}_{2} \mathrm{e}$ by 2020 . Id. at 9 . However, total emissions at the end of 2009 were at $49.5 \mathrm{GtCO}_{2} \mathrm{e}$. Id. at 15 . The report acknowledges that this presents "an emissions [problem] that urgently needs addressing." Id. at 7 . To create a likely chance of complying with the $2^{\circ} \mathrm{C}$ target in the long term, total greenhouse gas emissions in 2050 must be about $46 \%$ lower than their 1990 level, or about 53\% lower than their 2005 level. Id. at 9. See also Press Release, United Nations Framework Convention on Climate Change, History in the Making-The Inaugural Session of the ADP, May 2012, available at http://unfccc.int/press/news_room/ newsletter/items/6844.php [hereinafter History in the Making]. For position statements by major scientific institutes agreeing that significant human-caused climate change is occurring and needs to be redressed urgently, see The Scientific Consensus on Climate Change, WEATHER UNDERGROUND, http://www.wunderground.com/resources/climate/ 928.asp (last visited Apr. 8, 2013).

69 Outcome of the Work of the Ad Hoc Working Group on Further Commitments for Annex I Parties Under the Kyoto Protocol, Draft Decision, 8th Sess., Nov. 26, 2012-Dec. 7, 2012, U.N. Doc. FCCC/KP/CMP/2012/L.9 (Dec. 8, 2012).

70 History in the Making, supra note 68; BRIDGING THE EMISSIONS GAP, supra note 67, at 8 ("[S]cientists [have] reported that a gap was expected in 2020 between expected emissions and the global emissions consistent with the $2^{\circ} \mathrm{C}$ target, even if [voluntarily agreed-upon GHG reduction] pledges were implemented fully.").

71 History in the Making, supra note 68. 
Similarly, European Union fishing quotas were designed to protect EU waters from overfishing, but after decades of discussions are still known to be "imperfect instruments" in dire need of change. ${ }^{72}$ And after years of international efforts to combat human trafficking, the number of child victims of human trafficking rose no less than $27 \%$ from 2008 to $2011 .^{73}$ During the same period, adult human trafficking rose by $13 \%{ }^{74}$ In spite of the Convention on International Trade in Endangered Species of Wild Fauna and Flora (CITES) having been ratified by 175 members and thus being among the host of international conservation agreements that enjoy the largest membership, ${ }^{75}$ the annual trade in endangered animals worldwide is estimated to be worth USD 20 billion, trailing only guns and drugs on the illegal market and thus leading many countries to suggest that CITES has downright failed. ${ }^{76}$

"Insanity is doing the same thing over and over again, but expecting different results." 77 Using the word "insanity" for attempting to instigate change through traditional channels is taking too much of a negative attitude towards large-scale action. In fact, using a range of different avenues including, but not limited to, topdown solutions in the difficult quest it is to change serious national and transnational problems is very wise. But other venues have surfaced as equally or perhaps more effective. These will be examined next.

\section{B. “Bottom-up" Lawmaking}

Modernly, bottom-up solutions are often touted in legal scholarship to constitute more effective inroads on some of the most stubborn large-scale legal problems faced by society today than traditional top-

\footnotetext{
72 See, e.g., Eben Harrell, EU Discusses Fishing Quotas, TIME (Mar. 1, 2011), http://ecocentric.blogs.time.com/2011/03/01/eu-discusses-fishing-quotas/ (Agreeing on a new common fisheries policy by 2013 will be "a fierce political battle" with "even obvious problems ... [being] difficult to fix" at traditional EU level and thus recognizing that "we have to start thinking outside the box.").

73 IOM Reports Child Trafficking and Labor Trafficking Cases Are Rising, HUMANTRAFFICKING.ORG (Apr. 10, 2012), http://www.humantrafficking.org/updates/894.

74 Id.

75 What is CITES?, CONVENTION ON INTERNATIONAL TRADE IN ENDANGERED SPECIES OF WILD FAUNA AND FLORA, http://www.cites.org/eng/disc/what.php (last visited Apr. 8, 2013).

76 Patrick Scally, Trafficking in Endangered Animals on the Rise, GoKUnMING (July 26, 2012), http://gokunming.com/en/blog/item/2756/trafficking_in_endangered_animals _on_the_rise.

77 Rita MaE BRown, Sudden DEATH 68 (1983).
} 
down solutions. If not more effective, at least bottom-up solutions present viable additional methods of attacking a range of problems such as those often encountered the human rights and environmental fields. However, bottom-up lawmaking is not new. The concept can be traced to a classic scholarly article from 1961 that explained that a simple dichotomy between "the" government and "the" marketplace, each seen as one single unit, was not a good scientific approach to the study of public economies. ${ }^{78}$ Multiple actors were and are considered beneficial in not only economic, but also international environmental scholarship. $^{79}$

What makes bottom-up lawmaking and enforcement differ from top-down solutions is to a large extent that the former includes a diverse range of sub-state actors, mid-level technocrats, and, importantly, private parties and NGOs in addition to traditional government representatives. ${ }^{80}$ The actions of these parties coalesce around shared, on-the ground experiences and perceived selfinterests. ${ }^{81}$ They are often intended as self-regulation, at least at the initial stages of law formation. ${ }^{82}$ Bottom-up lawmaking can thus be considered to be a "subterranean, unchoreographed" process of local practice that eventually becomes law: ${ }^{83}$

These actors" "micro-decisions," their day-in and day-out choices, are designed to navigate a myriad of on-the-ground exigencies and demands. Collectively, these "micro-decisions" assume normative significance, as decisions become norms and as norms at once reflect and condition future decisionmaking and practice. Over time, this patchwork of on-the-ground decisionmaking hardens as law, often embedding in a formal legal instrument (treaty, statute, contract, administrative regulation). Thus, whereas top-down international lawmaking is a process of laws internalized into dayto-day practice, bottom-up lawmaking is a process whereby practices and behaviors are externalized as law.

\footnotetext{
78 Elinor Ostrom, A Polycentric Approach for Coping with Climate Change 32 (World Bank, Working Paper No. 5095, 2009).

79 Id.

80 Levit, supra note 66, at 395; Stacy Lozner, Diffusion of Local Regulatory Innovations: The San Francisco CEDAW Ordinance and the New York City Human Rights Initiative, 104 COLUM. L. REV. 768, 769 (2004).

81 Levit, supra note 66, at 395.

82 Id.

83 Id.

84 Hari M. Osofsky \& Janet Koven Levit, The Scale Of Networks?: Local Climate Change Coalitions, 8 CHI. J. INT'L L. 409, 429 (2008).
} 
Two important aspects of the bottom-up lawmaking process are worth highlighting. First, the background and identity of participants in bottom-up lawmaking processes is broader than that of traditional "lawmakers." Because the participants are linked to the "bottom" of traditional law-creation strata, state and national elites, diplomats, and politicians recede to the fringes. ${ }^{85}$ Instead, local public and private actors emerge as powerful drivers of change at the local level whether it be city, municipal, or a somewhat geographically larger, but still sub-national, level. "Private actors" cover both purely private individuals, but also, more typically, NGOs. In turn, these may be motivated by either altruism (in which case they are known as "Public-Interest NGOs" or "PINGOs") or by profit ("BusinessInterest NGOs" or "BINGOs").

Second, the decisions of these actors are legally consequential as they trickle trough unusual channels before eventually becoming law of either national or even international significance. "While isolated 'practitioner' decisions are not initially international 'law', according to a rather formal, narrow taxonomy, these decisions ultimately become law, either by embedding directly in formal legal instruments or by collectively placing pressure on and shaping legal outcomes." ${ }^{, 86}$ Accordingly, "through a process of bottom-up lawmaking, much international law surfaces." 87

Bottom-up lawmaking can also be viewed as a "polycentric system of lawmaking rather than a monocentric hierarchy." ${ }^{88}$ A polycentric order is one in which "many elements are capable of making mutual adjustments for ordering their relationships with one another within a general system of rules where each element acts with independence of other elements. ${ }^{, 89}$ Complex problems, such as climate change, that involve difficult adaptive, multi-scalar institutional and social dynamics that evolve rapidly and constantly arguably demand polycentric approaches, ${ }^{90}$ as it is unrealistic to think that such problems can be solved through one channel only.

The advantages of bottom-up, polycentric lawmaking are legion. First, inspiration by and involvement of those most highly affected by

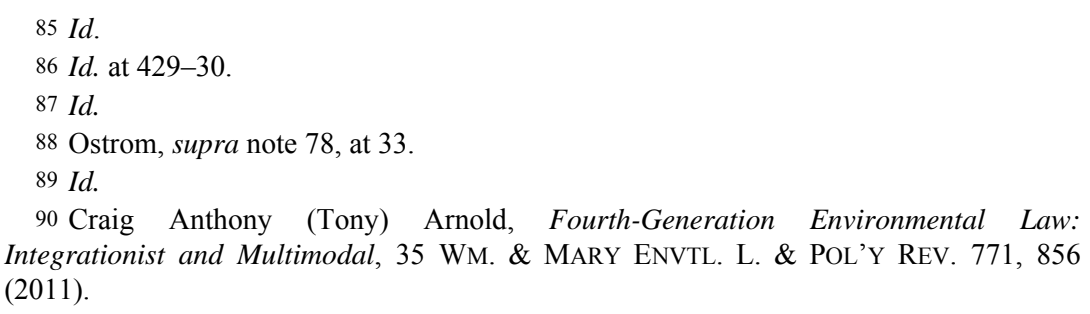


on-the-ground effects of new legal decisions is of obvious importance. Second, local actors possess great knowledge of various local (and often niche) legal, trade, environmental, and other issues. By adding a second layer of research, contemplation and input before governments take action that has effect for years, local actors contribute to the knowledge production required in connection with the creation of law and policy in valuable ways. Similarly, civil society actors often possess great financial, technical, and legal resources as well as valuable contacts to local networks that they are likely to be willing to share with public authorities if this furthers their own causes. This can help governments save scarce resources. "By 'utilizing the state for what it does best-raising resources and setting broad societal directions-while using nonprofit organizations for what they do best-delivering services at a human scale and innovating new fields-important public advantages can thus be gained." "91 Polycentric solutions of course also involve local authorities such as cities. These authorities enjoy great legal powers regarding, for example, "building and other codes, zoning, and various proprietary powers that can lead to substantial influence when considered collectively." 92

In addition to counteracting traditional top-down mandates that are often fixed, highly prescriptive, and inflexible - and thus considered inexpedient at the local level-law created from the bottom is more readily adaptable and thus better suited to unanticipated and complex contexts. ${ }^{93}$ However, the state still plays an active role in this context. This role becomes not only more effective, but also more legitimate when a wide range of stakeholders is involved in the regulatory process. $^{94}$ "[O]pening up the policymaking process to public consultation discussing where resources should better be used, increases the legitimacy of the regulating process and shares responsibilities over the final outcomes." 95 In other words, the regulated can be said to become regulators through bottom-up and public participation provisions. Diverse approaches such as those

\footnotetext{
91 Lozner, supra note 80, at 777.

92 Katherine A. Trisolini, What Local Climate Change Plans Can Teach Us About City Power, 36 FordHAM URB. L. J. 863, 873 (2009).

93 Lozner, supra note 80, at 773.

94 Lozner supra note 80, at at 774-76.

95 Romulo Silveira da Rocha Sampaio, Regulating Climate Change Risk at the Local Level-the Denver Experience: Greenprint or Greenwash?, 17 Mo. ENVTL. L. \& POL'Y REV. 356, 371 (2010).
} 
involving polycentric models and local actors stimulate and diffuse innovation, ${ }^{96}$ which results in greater potential for solutions that a narrower range of actors simply may not create.

Citizen participation and the public pressure it creates are known to further create an incentive structure for the formulation of effective regulatory structures at the national level. ${ }^{97}$ For example, local actors help create new social norms that eventually harden into law from the bottom, but they also contribute to the creation of top-down law when demands for action are moved from local to national government levels via lobbyism and other privately driven action. Thus, NGOs have resurfaced as transnational "norm entrepreneurs" 98 in helping to shape both domestic law (for example, the juvenile death penalty in the United States) and by adding a voice to international law formation and enforcement (as with CEDAW in San Francisco, which will be explained further below).

The local/national interface is also significant given what may be referred to as the "paradox of the lent targets." is local governments and other actors that are the main implementing bodies of, for example, legally binding agreements such as the Kyoto Protocol under which national governments are held responsible for meeting the targets. It is thus an advantage to involve local actors in the lawmaking process as early and as much as possible. Conversely, national governments alone cannot and do not act in a vacuum; they need the support of their constituents at all scales, including that of civil society. Sub-national actors should, for example, be included in the next possible climate change treaty regime. ${ }^{100}$

When it comes to the relevance of localized action to the global commons, an earlier widespread theoretical presumption was that only large-scale action was relevant for policies related to global public goods. ${ }^{101}$ However, research has shown that small and medium-scale units are also necessary components in this particular

96 Arnold supra note 90, at 858.

97 Lozner supra note 80, at 769.

98 Catherine Powell, Lifting Our Veil of Ignorance: Culture, Constitutionalism, and Women's Human Rights in Post-September 11 America, 57 HAStings L.J. 331, 377 (2005).

99 Ibon Galarraga et al., The Role of Regional Governments in Climate Change Policy, 21 ENVTL. POL'Y \& GOVERNANCE 164, 168 (2011).

100 Art Von Lehe, Cities, Climate and Cops, 19 SoutheASTERn ENVTL. L.J. 217, 228 (2011).

101 Ostrom supra note 78 , at 35. 
field. ${ }^{102}$ "An important lesson is that simply recommending a single governmental unit to solve global collective action problemsbecause of global impacts - needs to be seriously rethought and the important role of smaller-scale effects recognized. ${ }^{103}$ "[W]aiting for effective policies to be established at the global level is unreasonable." ${ }^{104}$ Even very small-scale action may be fruitful; for example, psychological research similarly supports the notion that involving groups of private actors in attempting to combat climate change can play an important role in fostering attitude and behavioral change at a broader scale as well. ${ }^{105}$ Local governments play an important role in this aspect too: because of their sheer proximity (both geographically and communicatively) to residents in their jurisdictions, they enjoy unique potential to influence civil society's actions despite their subjection to state and federal law. ${ }^{106}$

Finally, if traditional legal systems fail in regards to climate change or other problems of national and international significance, society will, through localized action, have developed the skills, social norms, and community connections to better manage adaptation situations better. ${ }^{107}$ Important social capital will have been built. ${ }^{108}$ At the very least, involving civil society in norm-creation that will affect everyone one way or another is an ethical advantage. ${ }^{109}$

Of course, bottom-up law making is no panacea; vulnerabilities exist in relation to this scheme as well. For example, the need for state and other scaled-up action is recognized in relation to issues that local actors simply cannot solve on their own. This holds true where national and supranational action is required as in the adoption, ratification, and national implementation of treaties. One important

102 Id.

$103 \mathrm{Id}$. at 35 .

104 Id. at 31.

105 Sarah Krakoff, Planetarian Identity Formation and the Relocalization of Environmental Law, 64 FLA. L. REV. 87, 114 (2012). See also the "nudge theory" in this author's parallel project on the effectiveness on localized action within climate change.

106 Trisolini, supra note 92 , at 873.

107 Krakoff, supra note 105, at 134, 139.

108 Arnold, supra note 90, at 858.

109 See Krakoff, supra note 105, at 139. For further recognized advantages and disadvantages of involving civil society in the creation and enforcement of law in general and through the Aarhus Convention, see also Marianne Dellinger, Ten Years of the Aarhus Convention; How Procedural Democracy is Paving the Way for Substantive Change in National and International Environmental Law, 23 COLO. J. INT'L ENVTL. L. \& POL'Y 309 (2012). 
example of this is possible future versions of the now-expired Kyoto Protocol. Just as governments need the support of their constituents as described above, so do local actors need their state and national governments to act. The interdependency between governments and people is simply a fact of life with which we have to contend in the creation of new law and legal regimes.

Another negative is that polycentric models have to contend with the risk of regulatory fragmentation and the resulting inefficiency and inaction. ${ }^{110}$ For example, "[c]ommentators have fingered a fragmented natural resources management structure in the United States as the culprit behind agency inaction, a lack of interagency learning, and neglect of climate change issues."111 Similarly, weak ties between local actors and government officials have already been shown to hamper effective action in relation to climate change in one major city in the United States. ${ }^{112}$

A typical criticism directed at current efforts to reduce GHG emissions in particular is that "too many projects and activities are operating at multiple scales and that the system is chaotic."113 For example, some projects have been accused of "rewarding actors who are not genuinely interested in reducing the threat of climate change but are instead looking for opportunities to gain funds and search for minimal ways of meeting project objectives."114 Other projects are known to create "perverse incentives"-as when land-use regulations result in higher timber prices - but are poorly enforced, resulting in additional incentives for clearing forests. ${ }^{115}$ But importantly, scholarship does not show that these and other attempts to "game" the system are products only when action is instigated at multiple levels or by multiple actors. Making this argument would fly in the face of logic. Throughout history, seeking out advantages for oneself has been common, even when doing so violates either the letter or the spirit of the law in question.

In short, this Article takes the view that there are more and more significant advantages of bottom-up lawmaking than there are

110 Thomas M. Gremillion, Setting the Foundation: Climate Change Adaptation at the Local Level 1221, 1231 (2011) (unpublished paper), available at http://law.lclark.edu/live /files/10605-4148tojcigremillionpdf.

111 Id.

112 Id. at 1231-32.

113 Ostrom, supra note 78, at 27.

114 Id. at 28.

$115 \mathrm{Id}$. at $29-30$. 
disadvantages, especially when it comes to technically and scientifically complex social issues.

\section{Aarhus Convention}

An example of how these and other advantages of involving civil society and local actors in lawmaking and enforcement have been recognized in a legal instrument is the UNECE Convention on Access to Information, Public Participation in Decision-making and Access to Justice in Environmental Matters adopted in Aarhus, Denmark, in 1998 (the Aarhus Convention, or the Convention). This calls for ratifying parties to guarantee the rights of access to information, to access to justice in environmental matters, and to public participation in decision-making. ${ }^{16}$ The importance of these procedural rights can be traced to Principle 10 of the Rio Declaration, which states that

[e]nvironmental issues are best handled with the participation of all concerned citizens, at the relevant level. At the national level, each individual shall have appropriate access to information concerning the environment that is held by public authorities . . . and the opportunity to participate in decision-making processes. States shall facilitate and encourage public awareness and participation by making information widely available. ${ }^{11}$

The Aarhus Convention is the first multilateral environmental agreement (MEA) that focuses exclusively on the obligations of states towards their citizens, and thus not only on parties' rights and obligations vis-à-vis each other. ${ }^{118}$ Among other unique aspects, the Convention encourages parties to actively involve civil society in a number of meaningful ways in relation to decision-making processes before substantive legal decisions are made. The Convention also seeks to involve the general public in the enforcement of at least the Convention itself. For example, it allows members of the general public to make communications to the Compliance Committee

116 Convention on Access to Information, Public Participation in Decision-Making and Access to Justice in Environmental Matters art. 1, June 25, 1998, Aarhus, Denmark, available at http://www.unece.org/fileadmin/DAM/env/pp/documents/cep43e.pdf [hereinafter Aarhus Convention].

117 Conference on Environment and Development, U.N. June 3-14, 1992, Rio Declaration on Environment and Development, 9 10, U.N. Doc. A/CONF.151/26 (Vol. I) (Aug. 12, 1992) [hereinafter Rio Declaration], available at http://www.un.org/documents /ga/conf151/aconf15126-1annex1.htm.

118 Ole W. Pedersen, European Environmental Human Rights and Environmental Rights: A Long Time Coming?, 21 GEO. INT’L ENVTL. L. REV. 73, 92-94 (2008). 
concerning a Party's compliance with the Convention. ${ }^{119}$ Other treaties typically only allow nation states to do so. Further, NGOs may nominate candidates for election to the Compliance Committee, also a unique participatory step in treaty contexts. ${ }^{120}$ The Compliance Committee has taken the lead among international agreements in opening its own meetings to observers, including those from the nongovernmental sector. ${ }^{121}$

As an international instrument, the Convention addresses only procedural provisions of the law. Accordingly, it does not speak to how nations should develop their substantive environmental laws. Nonetheless, the Convention has the potential to lead to substantively improved laws as well. ${ }^{122}$ This is mainly so because procedural provisions serve as a guarantee of the right to have an underlying substantive right adjudicated with the potential for the expansion upon substantive rights through adjudication. ${ }^{123}$ It is exactly through its procedural provisions that the Aarhus Convention is recognized to have "the potential to facilitate the same outcome as a substantive right in terms of assisting citizens in enforcing and pursuing environmental norms." 124 Public participation is an important stepping-stone on the way to more informed and thus better substantive decision-making. It is also a method of not passively relying on lawmakers to live up to their democratic promises, but also actively making them aware of the necessity to make environmentally sound decisions. ${ }^{125}$ In short, procedural provisions have the potential for assisting in avoiding poorly founded "ivory tower decisions." The Aarhus Convention principles are relevant to the development of both national and international law.

119 Background, U.N. ECON. COMM'N FOR EUR., http://www.unece.org/env/pp/ccback ground.html (last visited Apr. 9, 2013).

120 U.N. Econ. Comm'n for Eur., Report of the First Meeting of the Parties: Decision I/7 on Review of Compliance, Annex 18, U.N. Doc. ECE/MP.PP/2/Add 8 (Apr. 2, 2004).

121 NGOS IN INTERNATIONAL LAW: EFFICIENCY IN FLEXIBILITY? 152 (Pierre-Marie Dupuy \& Luisa Vierucci eds., 2008).

122 See Dellinger, supra note 109.

123 Id.

124 Pedersen, supra note 118, at 92, 108.

125 See Dellinger, supra note 109.

126 Id. at 335. 


\section{III \\ WHY LAW IS OBSERVED}

As legal practitioners and scholars, we tend to center our thinking on purely legal solutions to a host of societal problems. ${ }^{127}$ However, most of us probably rarely stop to ponder exactly why law has the importance to society that it does. This section describes some of the main reasons why people observe the law at all. The purpose of this is to demonstrate that motivating factors which may not immediately come to mind bear as much weight as traditional motivators, if not more.

Traditional thinking dictates that people follow the law for fear of financial and other punitive deterrents or because they seek compliance incentives, most often of a financial nature. Under this homo economicus theory, people do not worry about morality, ethics, or other people, but instead act selfishly and opportunistically in order to pursue the course of action that brings them the greatest material advantage. ${ }^{128}$ A follower of this school of thought, former Chief Justice Holmes of the United States Supreme Court, commented on what he saw as the folly of connecting law with morality more than a century ago in what later became known as the "bad man" notion of law: ${ }^{129}$

If you want to know the law ... you must look at it as a bad man, who cares only for the material consequences which such knowledge allows him to predict, and not as a good one, who finds his reason for conduct ... in the vague sanctions of conscience.... [W]hat does it mean to a bad man? Mainly, and in the first place, a prophecy that if he does certain things he will be subjected to disagreeable consequences by way of imprisonment or compulsory payment of money.

More than a century later, Holmes' "bad man" thesis is still routinely accepted by academics, lawyers, policymakers, regulators, and judges as a truth that does not require examination. ${ }^{131}$ This way of thinking has dominated public policy and many private institutions as

127 Undoubtedly, financial motivations and disincentives carry great weight as well, but as those appear to have taken a backseat in much of climate change law, they will not be discussed in any detail here.

128 STOUT, supra note 22, at 4.

129 Id. at 24.

130 Oliver Wendell Holmes, Jr., The Path of the Law, 10 HARV. L. REV. 457, 459-61 (1897).

131 STOUT, supra note 22, at 39-40. 
well. ${ }^{132}$ Contemporary experts trained in law and politics tend to not notice unselfish, pro-social behavior. ${ }^{133}$ But this situation is changing for the better. An understanding is developing that there are many more subtle ways in which legal rules influence behavior and that pure conscience plays a large role as well. ${ }^{134}$ Thus, it is not only judgments about the certainty and severity of official retaliation that drive our actions; informal sanctions and disapproval by our peers weigh on our consciousness too. ${ }^{135}$ As noted by Eric Posner, "people appear to obey norms both in order to avoid being sanctioned by others ('shame') and in order to avoid being sanctioned by their own conscience ('guilt')."136 Personal morality and social values play an equally important role. In fact, modern studies show that experts trained in law "greatly overestimate" the incidence of selfish behavior, and "seriously underestimate" the role conscience plays in directing human behavior and the extent to which we act for unselfish reasons. ${ }^{137}$ It is now recognized that we follow social norms not only out of concern for our reputations or fear of retaliation, but also because we think we ought to. ${ }^{138}$ Our capacity to act unselfishly is an advantage in and of itself, but even knowing that some people act unselfishly influences the behavior of even the purely selfish. ${ }^{139}$ Such "'second-order effects' allow a large number of small, marginally unselfish behaviors to support and reinforce prosociality." "140 This can be harnessed in disciplines such as human rights and environmental law where monetary/selfish interests have played a relatively large role in decision-shaping so far, but where more altruistic concerns would help develop the law in more equitable ways for the future.

132 Id. at 40.

133 Id. at 44.

134 STOUT, supra note 22, at 40, 71.

135 Tom R. Tyler, Why PeOple Obey the LAW 42 (2006).

136 Eric Posner, Efficient Norms, in THE NeW PALgRAVE DictionaRy of ECONOMICS AND THE LAW 2:20 (Peter Edman ed., 1998).

137 STOUT, supra note 22, at 70-71.

138 Id. at 34-35. "When [J.] Holmes advised [legal experts] to think of law only from the perspective of the bad man without a conscience, he was giving poor advice indeed. Rather than ignoring conscience, lawmakers will get better results if they put conscience into harness." Id. at 36.

139 Id. at $92-93$.

140 Id. at 93. 
The mere existence of laws leads many people to self-enforce based on "practical authority." 141 Practical authority drives people to follow the laws even where enforcement is unlikely. ${ }^{142}$ For example, a person follows practical authority when, with no other cars near, she waits at a red light very late at night. ${ }^{143}$ Similarly, the symbolic importance of laws is crucial to many. For this reason, laws may, paradoxically, be considered necessary even though they are not obeyed by many, are largely unenforced and unenforceable, and are argued by some to do as much harm as good. ${ }^{144}$ An example of this is laws against drugs. ${ }^{145}$ "“They're good,' people say, 'because they make a statement. They express the norms of civilized society." "146 This is so even though drug problems continue to exist in spite of years of broad illegality. The fact that most individuals still respect laws because of their symbolic existence despite, perhaps, any actual effect differs strikingly from previous self-interest models that still, but erroneously, dominate current thinking in law, political science, and sociology. ${ }^{147}$ Finally, religious reasons continue to be important to the observance of law to many. ${ }^{148}$

However, it is also important to note that people only obey laws they truly believe in:

People don't obey laws that they don't believe in. It isn't necessarily that they behave lawlessly, or that they'll steal whatever they can steal if they think they can get away with it. Most people try to comply, at least substantially, with what they believe the law to say. If they don't believe the law says what it in fact says, though, they won't obey it - not because they are protesting its provisions, but because it doesn't stick in their heads. Governments stop enforcing laws that people don't believe in. Laws that people

141 Crystal R. Dawson, Life in the Smoky Lane: An Evaluation of Environmental Tobacco Smoke and Bans on Smoking in Vehicles Containing Children, 4 PHOENIX L. REV. 885, 893-94 (2011).

142 Id.

143 Id.

144 Jessica Litman, Copyright Noncompliance (Or Why We Can't “Just Say Yes” to Licensing), 29 N.Y.U. J. INT’L L. \& POL. 237, 240 (1997).

145 Id.

146 Id.

147 TYLER, supra note 135 , at 178.

148 See, e.g., Intisar A. Rabb, The Islamic Rule of Lenity: Judicial Discretion and Legal Canons, 44 VAND. J. TRANSNAT'L L. 1299, 1315 (2011) ("Muslims conceived of God as the sole Legislator; obedience to Him through implementing His law was sacred duty. Muslim theologians and jurists had a relatively straightforward answer to the positivist question of why people should follow the law: religious texts - namely the Qur'ān and prophetic edicts - required it."). 
don't obey and that governments don't enforce get repealed, even if they are good laws in some other sense of the word. ${ }^{1}$

Examples of such laws are the now-repealed national fifty-fivemiles-per-hour speed limit, laws prohibiting consensual sodomy, or laws that prohibit minors from buying cigarettes. ${ }^{150}$

It is thus not correct that people are primarily motivated by shortterm interests that can be addressed via compliance or deterrence factors. ${ }^{151}$ Accordingly, "[t]o understand and use law more effectively, we must take account of the many ways law changes behavior, above and beyond creating material incentives" ${ }^{152}$ or through traditional legal deterrents.

The above considerations have been made about the effect of law in "positive myth" countries. Countries can also be categorized into "negative myth" countries: ${ }^{153}$

Individuals in societies with a "positive myth of law" tend to think that other people usually follow the law; that the law is a good thing and provides a fair way to resolve disputes; and that to break the law is "socially disgraceful." In contrast, individuals in societies with a "negative myth of law" tend to think that everyone else is regularly ignoring or breaking the law. "Negative myth" countries also have high levels of distrust in officials and government bureaucracy.

Examples of "negative myth" countries include Russia, Ukraine, and Armenia. ${ }^{155}$ The challenge in these countries is that "people tend to see law as simply a game, and as something to work around or over, not to simply follow."156

By and large, people will interpret their observations about the law on the basis of deeply rooted understandings of how the law works or does not work. ${ }^{157}$ "This means that even if there is change in the formal justice system, people are likely to view these changes, at least initially, with great skepticism and cynicism."158 In contrast to positive myth countries, people in negative myth countries tend to put

149 Litman, supra note 144, at 240.

150 Id.

151 TYLER, supra note 135 , at 166.

152 STOUT, supra note 22, at 237.

153 Cynthia Alkon, Lost in Translation: Can Exporting ADR Harm Rule of Law Development?, 2011 J. DisP. RESOL. 165, 173 (2011).

154 Id.

155 Id.

156 Id.

157 Id.

158 Id. 
a negative spin even on positive examples of how the law actually might work well or how government leaders may be following it. ${ }^{159}$ This, of course, presents an additional hurdle to any change of law in negative myth nations.

In contrast, people support authorities when they feel that their interests are being furthered by governments that perform quality work. ${ }^{160}$ People who regard legal authorities as legitimate are found to comply with the law more frequently. ${ }^{161}$ This presumably holds true in "negative myth" countries as well. In other words, procedure is of crucial importance to creating a good normative climate for decisionmaking and enforcement:

People may believe specific decisions are wrong, even wrongheaded, and individual judges unworthy of their offices and still continue to support the court if they respect it as an institution that is generally impartial, just and competent ... [certain people] often regard the way in which they are treated by governmental institutions as at least as important as the extent to which they achieve their substantive goals. It is being unfairly treated that disrupts the relationship of legitimacy to compliance, not receiving poor outcomes.

The important element in this context is to take steps to make people feel that they had an opportunity to take a meaningful part in the decision-making process, including having an opportunity to present their views, to be heard, and to have their views considered by the authorities. ${ }^{163}$ "People who feel that they have had a hand in the decision are typically much more accepting of its outcome, irrespective of what the outcome is." 164

In positive rule of law myth countries, scholars have found that procedural justice contributes to legitimacy. The studies on procedural justice have found that, for purposes of legitimacy, the process is more important to people than the outcome. If people find the process was fair or just, then they are more satisfied with the system than if they do not. Procedural justice scholarship examined underlying attitudes and views about the legal process and

159 Id.

160 TYLER, supra note 135 , at 50.

$161 \mathrm{Id}$. at 50, 64. When evaluating only courts, and not the broader legal enforcement regime, it is interesting to note that evaluations were also influenced by gender (men were more positive towards the system than women), education (those with less education were more positive), and by income (those with high income were more negative). Id. at 56 .

162 Id. at 73, 165, 172 (emphasis added).

163 Id. at 163.

164 Id. 
concluded that people think that a dispute resolution process was fair if the following key factors were present: that they were able to speak and be heard; that they were treated with dignity; and that the authority or decision-maker was neutral and fair. ${ }^{16}$

An example of how these concerns are promoted at the international level is the Aarhus Convention described above.

In short: people obey the law if it is legitimate, plausible, morally sound, expedient seen from a societal point of view, and if it has been reached in procedurally proper ways. ${ }^{166}$

\section{IV \\ THE INTERSECTION BETWEEN HUMAN RIGHTS AND ENVIRONMENTAL LAW}

New direction needs to be taken in both human rights and environmental law. This Article argues that bottom-up approaches present a viable and expedient alternative to traditional lawmaking when the two areas intersect. However, for this theory to be applicable, the two areas of law must share some common denominators. Were this not the case, using shared approaches would be unsound and illogical. This section shows how several commonalities exist and how environmental issues are already enhanced and enforced through a human rights approach.

As a threshold matter, human rights are "rights inherent to all human beings, whatever our nationality, place of residence, sex, national or ethnic origin, colour, religion, language, or any other status. We are all equally entitled to our human rights without discrimination. These rights are all interrelated, interdependent and indivisible. ${ }^{" 167}$ Further, they are inalienable and universal. ${ }^{168}$ It is thus "the duty of States to promote and protect all human rights and fundamental freedoms, regardless of their political, economic and cultural systems."

165 Alkon, supra note 153 at $173-74$.

166 TYLER, supra note 135, at 178.

167 What are Human Rights?, UNITED NATIONS OFFICE OF THE HigH COMM'R OF HUMAN RighTS, http://www.ohchr.org/EN/Issues/Pages/WhatareHumanRights.aspx (last visited Apr. 9, 2013).

168 Id.

169 Id. 
Among frequently recognized substantive human rights are the right to life $;{ }^{170}$ freedom from arbitrary interference in private or family life; ${ }^{171}$ the right to property; ${ }^{172}$ freedom from torture ${ }^{173}$ and slavery $;{ }^{174}$ the right to a fair trial ${ }^{175}$ and the freedom of speech, ${ }^{176}$ thought, conscience and religion. ${ }^{177}$ Non-discrimination is another significant principle in human rights law. ${ }^{178}$ Of course, newer considerations get added to the international human rights regime over time as the human knowledge and our socio-ethical considerations evolve. For example, in 1997, $\mathrm{UNESCO}^{179}$ adopted the Declaration on the Responsibilities of the Present Generation Towards the Future Generations, the preamble of which recognizes that "at this point in history, the very existence of humankind and its environment are threatened." ${ }^{\prime 80}$ The Declaration goes on to call for the protection of the environment by undertaking, inter alia, sustainable development, pollution prevention, and preserving natural resources needed for future generations. ${ }^{181}$ In November 2002, the United Nations Committee on Economic, Social and Cultural Rights issued a non-binding comment affirming, for the first time, that access to water was a human right and not a mere commodity to be bought and sold. ${ }^{182}$

170 International Covenant on Civil and Political Rights art. 6.1, Dec. 16, 1966, 999 U.N.T.S. 171 [hereinafter ICCPR]; Universal Declaration of Human Rights art. 3, Dec. 10, 1948, G.A. Res. 217(III) A, U.N. Doc. A/Res/217(III) [hereinafter UDHR]

171 UDHR, supra note 170, at art. 12.

$172 \mathrm{Id}$. at art. 17.

173 Id. at art. 5.

174 Id. at art. 4.

175 See, e.g., id. at art. 10.

$176 \mathrm{Id}$. at art. 19.

177 ICCPR, supra note 170, at art. 18; UDHR, supra note 170, at art. 18.

178 What are Human Rights?, supra note 167.

179 The search for peace, the respect for diversity and human rights are among the central pillars of UNESCO's work. UNESCO Adopts Declaration on the Responsibilities of Present Generations Towards Future Generations, UNESCO (Nov. 12, 1997), http://www.unesco.org/bpi/eng/unescopress/97-214e.htm.

180 Declaration on the Responsibilities of Present Generations Towards Future Generations, UNESCO (Nov. 12, 1997), http://www.unesco.org/cpp/uk/declarations /generations.pdf (emphasis added).

181 Id.

182 Human Rights, HUMAN RigHTS ADVOCACY (2011), available at http://www.hradv .org/node/33. 
Whereas the right to a healthy or adequate environment has been considered a human right in its own right, ${ }^{183}$ the most common way of linking environmental rights to the human rights umbrella is, however, still to consider environmental rights to stem from what may be seen as "traditional" human rights. The link between the two areas has been officially recognized this way. For example, regional human rights bodies such as the African Commission on Human Rights, the European Convention on Human Rights, and the InterAmerican Commission on Human Rights have associated the right to life with the right to a healthy environment. ${ }^{184}$ In a 1994 report, U.N. Special Rapporteur Fatma Z. Ksentini similarly formulated strong links between environmental protection and the fundamental human rights to life, health, and culture. ${ }^{185}$ In a 2008 resolution, the U.N. Human Rights Council further emphasized the fact that "climate change poses an immediate and far-reaching threat to people and communities around the world and has implications for the full enjoyment of human rights." ${ }^{\text {"186 }}$ The Aarhus Convention similarly recognizes the "right of every person of present and future generations to live in an environment adequate to his or her health and well-being. ${ }^{187}$ The European Convention on Human Rights considers threats to the environment to fall under the umbrella of rights to private and family life. ${ }^{188}$ Landmark human rights cases have also upheld the link between environmentally adverse actions and the rights to private and family life. ${ }^{189}$ The Supreme Courts of India, the Philippines, and Montana, as well as trial courts in Nigeria, have all

183 See, e.g., African Charter on Human and Peoples' Rights art. 24, June 27, 1981, 21 I.L.M. 58 (1982); Organization of American States, Additional Protocol to the American Convention on Human Rights in the Area of Economic, Social and Cultural Rights art. 11, Jan. 1989, 28. I.L.M. 156 (1989); Aarhus Convention, supra note 116, at art. 1.

184 Svitlana Kravchenko, Right to Carbon or Right to Life: Human Rights Approaches to Climate Change, 9 VT. J. ENVTL. L. 513, 523 (2008).

185 Comm. on Human Rights, Sub-Comm. on Prevention of Discrimination \& Protection of Minorities, Special Rapporteur, Human Rights and the Environment, Final Report, U.N. Doc. E/CN.4/Sub.2/1994/9 (July 6, 1994) (prepared by Mrs. Fatma Zohra Ksentini, Special Rapporteur).

186 Office of the High Commission for Human Rights, U.N. Human Rights Council, 7th Sess., U.N. Doc. A/HRC/7/L.21/Rev.1 (Mar. 26, 2008), available at http://ap.ohchr.org /documents/E/HRC/resolutions/A/HRC/7/L.21/Rev.1.doc.

187 Aarhus Convention, supra note 116, at art. 1.

188 Convention for the Protection of Human Rights and Fundamental Freedoms, Nov. 4, 1950, 213 U.N.T.S. 222, available at http://www.echr.coe.int/NR/rdonlyres/D5CC24A7 -DC13-4318-B457-5C9014916D7A/0/EnglishAnglais.pdf [hereinafter European Convention].

189 Lopez Ostra v. Spain, 16798 Eur. Ct. H.R. 90 (1994); Fadeyeva v. Russia, 53157 Eur. Ct. H.R. 99 (2006); Taskin v. Turkey, 46117 Eur. Ct. H.R. 99 (2004). 
applied substantive environmental human rights claims to the resolution of cases. ${ }^{190}$ Finally, fair trade considerations regarding coffee and other agricultural products as well as the occasionally controversial operations of large multinational oil companies in the Global South also demonstrate how human rights and environmental law intersect both in theory and application.

As demonstrated, there are thus several recognized links between "traditional" human rights and "environmental human rights." A common platform for the development of both areas of law separately and for the development of environmental law through a human rights approach thus exists. On this foundation, the remainder of the Article will examine how five select metropolises have developed their human rights and/or environmental law schemes from the bottom-up and what lessons can be learned from these experiments.

\section{V \\ A TAle OF Five CitiEs: BotTOM-UP, POLYCENTRIC APPROACHES TO LAW DEVELOPMENT}

\section{A. San Francisco Human Rights Law: International Inspiration Leads to Local Action}

In 1998, San Francisco became the first, and still only, U.S. city to adopt a local ordinance reflecting the principles of the Convention on the Elimination of All Forms of Discrimination against Women (CEDAW). ${ }^{191}$ CEDAW is often described as an international bill of rights for women. ${ }^{192}$ Consisting of a preamble and thirty articles, it sets up an agenda for national action to end discrimination against women defined as

any distinction, exclusion or restriction made on the basis of sex which has the effect or purpose of impairing or nullifying the recognition, enjoyment or exercise by women, irrespective of their marital status, on a basis of equality of men and women, of human

\footnotetext{
190 Kravchenko, supra note 184, at 523.

191 Convention on the Elimination of All Forms of Discrimination Against Women: What Does CEDAW Mean?, FRIENDS OF THE S.F. COMM'N ON THE STATUS OF WOMEN, http://www.friendscosw.org/cedaw (last visited Apr. 10, 2013).

192 Convention of the Elimination of All Form of Discrimination Against Women: Overview of the Convention, UN DIV. FOR THE ADVANCEMENT OF WOMEN, http://www.un.org/womenwatch/daw/cedaw/ (last visited Apr. 10, 2013).
} 
rights and fundamental freedoms in the political, economic, social, cultural, civil or any other field.

The history of and ongoing CEDAW work in San Francisco demonstrates how international principles can become legally binding at the local level even if no action is taken at the national level. Further, the San Francisco CEDAW experience shows how public participation does not require an initial mandate or other impetus from "above"; civil society can speak so loudly and effectively that governments choose to listen and act. San Francisco serves as an example of how community deliberation and critical involvement by NGOs can stand at the forefront of new governance models.

Inspired by a 1995 United Nations (UN) World Conference on Women and frustrated by the continued inability to have the United States Congress ratify the UN version of CEDAW, the women of San Francisco organized a successful effort to have the city adopt a local ordinance reflecting CEDAW principles in $1998 .{ }^{194}$ These women organized under a coalition of local, national, and international NGOs such as Amnesty International USA, the Women's Foundation of San Francisco, and the Women's Institute for Leadership Development for Human Rights (WILD). ${ }^{195}$ Spearheaded by WILD, this coalition was in charge of the process of educating community members about the San Francisco version of CEDAW (hereinafter, "CEDAW" will only refer to the San Francisco ordinance) and gaining support for its local adoption. ${ }^{196}$ The consortium of NGOs was subsequently joined by and closely cooperated with the San Francisco Commission on the Status of Women (COSW), the San Francisco Human Rights Commission, and the County Board of Supervisors, which is the local legislative branch. ${ }^{197}$ The ordinance itself was drafted by COSW, the Office of the San Francisco Board of Supervisors President, and the City Attorney, and was enacted after a series of public hearings. ${ }^{198}$ Behind the passage of the ordinance were four primary motivators:

193 Id.

194 ANU MenON, S.F. DeP'T ON THE StATUS OF WOMEN, HuMAN RightS IN ACTION: SAN FRANCISCO'S LOCAL IMPLEMENTATION OF THE UNITED NATIONS' WOMEN'S TREATY (CEDAW) (2010), available at http://www.sfgov3.org/Modules/ShowDocument aspx?documentid $=314$. The United States is the only industrialized nation in the world that has yet to ratify CEDAW. Powell, supra note 98, at 379.

195 MENON, supra note 194, at 1; Lozner, supra note 80, at 778-79.

196 Powell, supra note 98 , at 378.

197 MENON, supra note 194, at 1.

198 Lozner, supra note 80 , at $778-79$. 

and Human Rights Law from the Bottom Up

1. to demonstrate to federal officials how critical CEDAW is to women in the United States;

2. to help bring women's issues under the rubric of human rights;

3. to bring the weight of international human rights into local communities; and

4. to provide communities with a proactive rather than a retroactive strategy to promote change. ${ }^{19}$

CEDAW addresses "second-generation" discrimination in the city (and thus county) of San Francisco. ${ }^{200}$ "First-generation" discrimination was the "deliberate exclusion or marginalization because of race, ethnicity, national origin, sex, age, religion, sexual orientation, or disability." 201 In contrast, second-generation discrimination involves "structures of decision-making, patterns of interaction, and cultural norms that are not immediately discernible at the level of the individual."202

To prevent or alleviate discrimination, San Francisco has implemented several innovative programs. Two examples are the Gender Analysis Tool (Tool) and "gender responsive budgeting" (GRB). The Tool sets forth a framework for analyzing the cultural, economic, social, civil, legal, and political relations between women and $\operatorname{men}^{203}$ in order to assist the city in implementing CEDAW principles. In a five-step process, the Tool requires city departments to analyze their operations for possible patterns of gender, race, and other identities in areas such as who is being served, hired, or awarded funds. ${ }^{204}$ It also asks the departments to address the impact of possibly discriminatory measures on city services, employment practices, and budget allocations. ${ }^{205}$ GRB requires city representatives to "review[] budget allocations for biases that can arise because a person is male or female, and considers disadvantage suffered as a result of ethnicity, poverty status, immigration, disability, age, or other demographic characteristics. "206 In an attempt to create

199 Id. at 778 (emphasis added).

200 Id. at 771 .

$201 \mathrm{Id}$.

202 Id.

203 Id. at 781

204 MenON, supra note 194, at 3. The five steps are: Define Vision and Desired Outcomes; Collect and Analyze Data; Develop Options; Prioritize Strategies and Create an Action Plan; and Develop a Monitoring Mechanism. Id. at 3-4.

205 Id. at 3.

206 Id. at 8. 
synergism between local government innovation and private action, the city is working towards having the private sector implement GRB as well. ${ }^{207}$ Similarly, the Department on the Status of Women works with the Calvert Group, "one of the largest families of socially responsible mutual funds in the United States," and Verité, an international labor and human rights monitoring organization, in promoting the San Francisco Gender Equality Principles (GEP) Initiative. ${ }^{208}$ This latter government-based initiative provides private companies with practical tools for use in improving gender equality at all corporate levels. ${ }^{209}$

San Francisco uses collaborative governance in other ways as well. For example, a task force composed of both governmental and nongovernmental representatives has been established to monitor the implementation of the ordinance pursuant to the ordinance itself. ${ }^{210}$ Further, policy bodies meet regularly and in public to maximize transparency and public input. ${ }^{211}$ In short, public participation forms an official part of the local legal framework.

Just as the creation of CEDAW in San Francisco was untraditional, so is the enforcement of the ordinance, at least seen from a traditional "hard law" point of view. The ordinance seeks to secure compliance through reporting, monitoring, and capacity building ("collaborative enforcement"), but features no "coercive enforcement." 12 The only type of traditional law enforcement under CEDAW is the city's subpoena power, which can be used to require participation in information gathering regarding possible violations. ${ }^{213}$ Otherwise, the normative model is "premised upon the "persuasive power of legitimate legal obligations." 214 Stakeholders are motivated by the internalization of rules and norms over time as they participate in deliberations and developments of the regime in what is locally considered to be legally and socially expedient ways. Thus, the

207 Id. at $10-11$.

208 Id. at 11. GEP is a set of aspirational principles within the following seven fundamental gender equality areas: employment and compensation; work-life balance and career development; health, safety, and freedom from violence; management and governance; business, supply chain, and marketing practices; civic and community practices; civic and community engagement; and transparency and accountability. Id.

209 Id.

210 Powell, supra note 98 , at 379.

211 MENON, supra note 194, at 9.

212 Lozner, supra note 80 , at 783.

213 Id. at 798.

214 Id. at 784 
stakeholders are not "coerced" 215 by anticipation of a more traditional-style top-down enforcement methodology. Thus, the San Francisco enforcement model mirrors the United Nations human rights regime upon which the ordinance is based in that it does not compel city agencies to follow up on their action plans but - through monitoring and reporting - seeks to shape behaviors and norms of participants in the problem-solving process ${ }^{216}$ via positive motivation.

The advantages of cooperative rather than traditional enforcementbased compliance are, among other factors, that participants may feel more free to share information-even that which appears to reflect on them in negative ways - with government agencies without fear of being sanctioned. In other words, in models with traditional "hard" enforcement, actors may withhold information that could lead to them being sanctioned where information-sharing would otherwise be fruitful seen from the ultimate viewpoint of reaching the substantive goals of the instrument in question. An example of such a "perverse incentive" will be seen in connection with the New York human rights system below. Cooperative enforcement styles rather than coercive ones are also promoted by and applied under international agreements such as the UNFCCC, the Kyoto Protocol, and the Aarhus Convention.

Typical criticism of collaborative enforcement is that some degree of rule enforcement is needed, for example, in cases of refusals to remedy flagrant violations of the law and the appurtenant compensation of victims. ${ }^{217}$ Further, critics note that difficulties relating to experiments in participatory problem solving, such as resistance to modern decision-making processes and the failure to institutionalize changed practices, are potentially exacerbated when the legislation developed does not explicitly provide for an enforcement mechanism. ${ }^{218}$ These concerns should be noted by future policymakers and legal scholars. However, this Article will proceed under the view that although collaborative enforcement may at first blush seem "toothless," it does present the significant and recognized advantage that if we as civil society are to form a meaningful, active part of iterative norm-making processes, we will be more likely to adhere to the law we have helped develop, thus calling for less top-

\footnotetext{
215 Id.

216 Id.

217 Id. at 796.

218 Id. at 783
} 
down, coercive enforcement to begin with. In other words, this "carrot-instead-of-stick" method is more procedurally sound and presents a better potential for substantive results as well.

What results have been obtained by the San Francisco action? As a threshold matter, it is important to remember that whereas identifying procedurally improved methods can be relatively straightforward, distinguishing between the cause and effect in relation to any substantive results in this area is difficult. If, for example, it were possible to show that public or private actors have become "less discriminatory" than before, it would still be next to impossible to verify whether this was because of CEDAW per se or, rather, because the thinking of such actors has evolved in positive ways for other reasons instead or as well. Nonetheless, some on-the-ground patterns indicate at least some degree of both procedural and substantive success just as the attitude held by competencies and stakeholders in San Francisco has improved positively. First, the City Charter was changed by referendum in 2008 to encourage the appointment of more women, minorities, and people with disabilities. ${ }^{219}$ While discrimination undoubtedly still exists in San Francisco, and while it appears that some agencies have merely chosen to add services rather than to affirmatively change their practices, ${ }^{220}$ a new awareness of gender-related issues among agencies has, however, been pinpointed. ${ }^{221}$ These agencies have "uniformly appreciated the human rights pro-active application as being more effective than the reactive discriminatory complaint-driven approach." ${ }^{, 22}$ Department personnel have also, in large, been receptive to the gender analysis methodology and, on their own initiative rather than because of top-down mandates, began evaluating their programs for any possibly existing discrimination. ${ }^{223}$ Other indicia of success are that a dedicated "Girls Unit" was created at Juvenile Hall after the adoption of CEDAW, 224 just as the findings about discrimination within the Department of the Environment greatly influenced the establishment of the Department's policies and procedures, which now form a permanent part of the Department operations. ${ }^{225}$ Thus, several procedurally

\footnotetext{
219 MENON, supra note 194, at 9.

220 Id. at 12; Lozner, supra note 80 , at 785-86.

221 Lozner, supra note 80, at 783.

222 Id.

223 MENON, supra note 194, at 5.

224 Id.

225 Id. at 7.
} 
sound results exist. These "bel[y] traditional criticisms of collaborative governance, successfully linking aspirational standards to a system of problem solving by granting specificity to general norms, creating a dynamic system of collaboration between nonprofits and local government, and using formal law to legitimate informal law.",226

Substantive results are, as mentioned, harder to trace to CEDAW in particular, just as it would be outside the scope of this Article to go in depth with such results. The author's research into city documentation thus only discloses that any possibly related results appear to range from relatively modest to good. For example, when it comes to the retention of a diverse workforce, the city's materials show that before CEDAW, women held $33 \%$ of professional positions although the available labor pool of women was $48 \% .{ }^{227}$ One person of color held a professional level position. ${ }^{228}$ Now, $69 \%$ are women and $39 \%$ are "minorities.", 229 The percentage of women members of commissions and boards also rose from forty-eight to fifty-one from 2007 to $2011,{ }^{230}$ but the author was not able to identify corresponding "before and after" figures for minority membership of commissions and boards.

San Francisco presents a good example of how international law can become "localized" if seen as important enough to bypass the lack of federal-level action. The interaction among government agencies, PINGOs, and BINGOs resulted in a highly iterative process in which an international instrument was interpreted and became successfully internalized into domestic law. International law is thus far from always the mere creation of law in a relatively formal, static process at the national or supranational level, but rather, can also be an evolutionary process resulting in legally binding action at the subnational level. This evolutionary process has been recognized to lead to locally more relevant and more democratically accepted law. Although arguably difficult to achieve, a more participatory localized approach to the adoption of international treaty principles can thus be a boon to society. This process is not unlike the localization of, for example, languages. This also requires considerable creativity,

\footnotetext{
226 Lozner, supra note 80 , at 770.

227 MENON, supra note 194, at 7.

228 Id.

229 Id.

230 Id. at 5-7.
} 
consideration of the consequences of the written word, addition of crucial aspects of what is to be conveyed, and the omission of others, rather than the mere re-creation of text. Some aspects of both language and law are, in fact, impossible to emulate locally whereas others are not necessary. When some aspects are added, the original source is enhanced.

Through a more participatory approach to the adoption of international treaty principles, the dichotomy between what is often seen as the "core" of international law and its "periphery" becomes, if not erased, at least undermined. ${ }^{231}$ This is a positive: breaking down traditional, rigid barriers presents new opportunities for legal growth. Further, the participatory approach constitutes an example of democracy at work in indirect, yet positive, ways; for example, the United States is the only industrialized nation in the world that has yet to ratify CEDAW. ${ }^{232}$ Nonetheless, through the steps mentioned above, civil society managed, through a longer path than in more "treatyfriendly" countries, to reach the same ultimate goal, ${ }^{233}$ namely the adoption of the substantive principles of law, albeit in a local version. Government-level resistance towards the ratification of popular treaties may be perceived to be a failure of our democracy at work. ${ }^{234}$ However, the San Francisco experience shows that this perception is not correct. The experience exemplifies how democracy is redefining itself in the United States: where scaled-up action is not forthcoming at the national level, scaled-down action takes over by civil society taking hitherto unforeseen paths towards desirable legal developments in cooperation with local governments.

This, however, may present a problem of constitutional significance: the United States Constitution assigns the power to make and adopt treaties to the federal government, but when state and local governments "adopt" human rights treaties and other international norms in response to constituent pressures that are more effectively mobilized at the subnational level, ${ }^{235}$ the balance between federal and state powers may be disturbed. This is likely to be of concern to elected and potential lawmakers at the national and the sub-national levels. To be sure, localized action with potential national or even international ramifications invites dialogue about

\footnotetext{
231 Powell, supra note 98, at 383.

232 Id. at 379.

233 Id. at 383.

234 Id.

235 Id. at 380.
} 
who is better situated to take action: national or sub-national actors. Both have an important role to play. To solve complex legal problems, decisions have to be taken at multiple scales, just as state and federal actors have overlapping jurisdictions in relation to several legal issues such as environmental law. This implies the emerging theory of Dynamic Federalism under which

"federal and state [and thus also local] governments function as alternative centers of power and any matter is presumptively within the authority of both the federal and state governments.". . Scholars of Dynamic Federalism reject the "minimal overlap" model in which there is a "particular allocation of at least primary regulatory authority between the states and the federal government," replacing it with one "in which multiple levels of government interact in the regulatory process." As a result, Dynamic Federalism "reject[s] the traditional state optimization model for an adaptive one."

Such dialogic federalism is considered desirable by many "as opportunities for negotiation and dialogue can provide a means to clarify, articulate and convert abstract international human rights and other norms into concrete, practical, and democratically accepted domestic laws and policies. ${ }^{\text {237 }}$ It may thus be that instead of today's heavy focus on states' rights versus federal rights, we as a society will eventually have to accept a mixed approach to lawmaking, including law with an international impetus. This is so because unstoppable action is, as shown, springing up at the local level regardless of the federalism concerns of some. Modernly, "[w]ith the 'disaggregation' of sovereignty, permeability of national borders, and ascendancy of transnational civil society, it is hardly surprising that international human rights law seeps into our national legal culture through multiple points of entry." 238

Just as international instruments and other legal inspiration can have sub-national implications, so can sub-national action eventually lead back to the international level as demonstrated by the San Francisco CEDAW development. Taking the lead from San Francisco, forty-five nations have now undertaken gender responsive budgeting initiatives at the national and/or sub-national levels of

236 J.B. Ruhl, Climate Change Adaptation and the Structural Transformation of Environmental Law, 40 ENVTL. L. 363, 428 (2010) (quoting Kirsten H. Engel, Harnessing the Benefits of Dynamic Federalism in Environmental Law, 56 EMORY L. J. 159, 161, 176 (2006)).

237 Powell, supra note 98, at 381.

238 Id. at 381. 
government. ${ }^{239}$ The Gender Equality Principles were, in part, based on global women's principles developed by the UN Global Compact and UNIFEM, but were further developed in San Francisco. The resulting seven aspirational principles now help companies around the world achieve greater gender equality. ${ }^{240}$ The principles have also influenced work performed by the World Bank Group, the Global Reporting Initiative, and the International Finance Corporation. ${ }^{241}$ Thus, knowledge and experience gained at the local level can help frame and redefine not only actual on-the-ground steps at the local level, but also help frame and redefine the discourse and eventually development of international law and other action. The circle becomes full when sub-national experiments and discourse take direction from the supranational level before being adapted in a local version and then leading back to international action. The potential for synergism between the creation of national and international law is clear.

\section{B. Human Rights Law in New York City: An Enforcement-based Model}

Just as civil society in San Francisco sought to adopt a localized version of CEDAW, so did a coalition of PINGOs in New York City (NYC), but with much less success so far. Although a CEDAW-based ordinance has not yet been adopted, New York City still employs a strong human rights regime that is undergoing its own development, albeit not based on clear international inspiration. This regime highlights the possible pitfalls of relying on traditional lawenforcement within human rights. Collaborative methods may prove more fruitful.

The New York City Human Rights Initiative (NYCHRI) is very active in promoting the adoption of a CEDAW-inspired law in New York. This group is "a citywide coalition of community-based organizations, service providers, advocacy groups, policy makers, labor unions and human rights activists and educators working to strengthen human rights standards in . . . New York City." "242 The

239 MENON, supra note 194, at 8.

240 Id. at 11.

241 Id.

242 NEw York CITY HUMAN Rights INITIATIVE, http://www.nychri.org/ (last visited Apr. 10, 2013) [hereinafter NYCHRI]. The coalition includes the Women of Color Policy Network, the Human Rights Project at the Urban Justice Center, the New York Civil Liberties Union, Legal Momentum, Amnesty International USA, and the American Civil Liberties Union. 
NYCHRI has proposed legislation that draws from a broad set of human rights principles of non-discrimination, participation, accountability, and transparency, including CEDAW. ${ }^{243}$ The proposed ordinance would expand on the current New York City Human Rights Law and was introduced to the New York City Council in $2010 .^{244}$ The proposal is, at the time of this writing, still before the Committee on Civil Rights. ${ }^{245}$ It has once before suffered political defeat, ${ }^{246}$ perhaps because a participatory problem-solving approach such as that of the proposed ordinance may not be palatable in NYC in general and may also be incompatible with the NYC Commission on Human Rights' more traditional rule-enforcement methodology, ${ }^{247}$ which will be examined further below.

Human rights are currently enforced in NYC by the New York City Commission on Human Rights (CCHR) and the City Law Department. ${ }^{248}$ The legal foundation is Title 8 of the Administrative Code of the City of New York, also known as the New York City Human Rights Law (the Human Rights Law, or the Law). ${ }^{249}$ In 2001, the Committee on Civil Rights of the Association of the Bar of the City of New York issued a report detailing the prevalence of discrimination in the City, the "crippled state of the CCHR, and the need for major reform."250 Suggestions for improving the human rights regime included a more vigorous enforcement of the Human Rights Law, more publicity about the law as well as about the role of the CCHR. ${ }^{251}$ The report "emphatically supported reframing discrimination as a law enforcement issue," rather than a participatory law creation issue, arguing that the threat of sanction is necessary to improve deterrence. ${ }^{252}$ In response, Mayor Bloomberg committed to revitalizing the CCHR and promised to focus on a strengthened

\footnotetext{
243 Id.

244 Id.

245 Legislation: Identifying, Eliminating and Preventing Discrimination, and Promoting Human Rights in Governmental Operations, NEW YORK CITY COUNCIL, $\mathrm{http} / / /$ legistar.council.nyc.gov/LegislationDetail.aspx?ID=679918\&GUID=960F221E-C 810-40E9-AF16-2EC4547ED586\&Options $=\&$ Search $=($ last visited Apr. 10, 2013).

246 NYCHRI, supra note 242.

247 Lozner, supra note 80, at 791.

248 NEw YORK CITY COMMISSION ON HUMAN RiGHTS, http://www.nyc.gov/html /cchr/home.html (last visited Apr. 10, 2013); Lozner, supra note 80, at 791.

249 New York CITY COMMISSION ON HUMAN RIGHTS, supra note 248.

250 Lozner, supra note 80, at 793.

251 Id.

252 Id. (emphasis added).
} 
traditional enforcement approach rather than mediation or community-involved relations. ${ }^{253}$ The importance of law enforcement has also been emphasized by City Council members asserting that "legislation without adequate enforcement lacks impact."254 Accordingly, an experienced prosecutor was appointed to chair the CCHR, which currently consists of nine Commissioners with, for the most part, non-legal backgrounds. ${ }^{255}$

The New York City Human Rights Law is one of the most comprehensive civil rights laws in the nation, ${ }^{256}$ even more so than federal law. ${ }^{257}$ The Law prohibits discrimination in employment, housing, and public accommodations. ${ }^{258}$ In addition, the Law affords protection against discrimination in employment based on arrest or conviction record and status as a victim of domestic violence, stalking, and sex offenses. ${ }^{259}$ Finally, the Law prohibits retaliation and bias-related harassment, including cyber-bullying. ${ }^{260}$ The Human Rights Law does not feature public participation provisions nearly as strong as those of other legal instruments analyzed in this Article, and will thus not be addressed further.

It is important to consider the traditional enforcement aspect of the Human Rights Law as it stands in relatively stark contrast to the more cooperative solutions described in this Article. The CCHR may on its own initiative investigate suspected violations of the law. ${ }^{261}$ Affected victims may also file a complaint with the Law Enforcement Bureau of the CCHR. ${ }^{262}$ If a complaint is filed and the required mediation fails, the Commission makes either a "probable cause" or a "no probable cause" determination. ${ }^{263}$ If probable cause is found, the case is referred to the Office of Administrative Trials and Hearings, where

253 Lozner, supra note 80, at 793, 795; Sam Dolnick, Rights Revival? One City Agency that Didn't Take a Budget Cut, Village Voice, May 7, 2002, at 24, http://www.villagevoice.com/2002-05-07/news/rights-revival/.

254 Lozner, supra note 80 , at 795.

255 Id. at 793; Commissioners, NEW YORK CITY COMMISSION ON HUMAN RigHTS, http://www.nyc.gov/html/cchr/html/commissioners.html (last visited Apr. 10, 2013).

256 New YoRK CITY COMMISSION ON HUMAN RighTS, supra note 248.

257 Lozner, supra note 80, at n.147.

258 NEW YORK CITY COMMISSION ON HUMAN RigHTS, supra note 248.

259 Id.

260 Id.

261 Commission on Human Rights, N.Y.C. Admin Code § 8-105(4)(a) (1991).

262 Id.; Michael R. Bloomberg \& PAtricia L. Gatling, N.Y.C. COMmission ON HUMAN RIGHTS 11 (2012), available at http://www.nyc.gov/html/cchr/pdf/bluebook_2012 _eng.pdf.

263 BlOOMBERG \& GATLING, supra note 262, at 9. 

and Human Rights Law from the Bottom Up

an administrative law judge issues a Report and Recommendation. ${ }^{264}$ On this basis, the Commission issues its Final Decision and Order. ${ }^{265}$ The Commission's broad remedial powers include requiring respondents to take appropriate employment action such as hiring, reinstating, or promoting complainants; to provide reasonable accommodation; and/or compensating complainants for lost wages and emotional distress. ${ }^{266}$ In addition, the Commission has the power to order respondents to implement various anti-discrimination policies. ${ }^{267}$ Importantly, the Commission may impose a civil penalty of up to $\$ 250,000$ if the Commission finds that the discrimination was the result of a willful or malicious act. ${ }^{268}$

To those preferring more traditional, adversarial-style law enforcement, it is fair to say that New York follows just such a "takeno-hostages" approach, as both the Mayor and several City Council members promised to do. This, however, conflicts with modern theories holding that cooperative law enforcement is often equally, if not more, substantively effective. Further, adversarial problem solving may not lead to the fruitful exchange of information that could otherwise take place before problems escalated to become actual "conflicts." In other words, it may lead to perverse incentives for withholding information:

[The] conception as [being] primarily a law enforcement agency is inconsistent with the logic of participatory problem solving. The participatory problem-solving approach of the San Francisco CEDAW ordinance depends on the willingness of agencies to identify their problems and to involve a facilitating body in the development of action plans to remedy these problems. Agencies are unlikely to provide this information to a body empowered to use it against them in the context of a lawsuit. The enforcement model thus creates perverse incentives in information sharing. ${ }^{26}$

Is the New York scheme nonetheless successful? Procedurally, the Commission's new two-pronged approach-an intensive initial interview of the complainant followed by an immediate investigation of the facts alleged - provides investigators with a greater-than-before

264 Id. at 9-10. The CCHR may also refer cases to the Corporate Counsel to commence a civil action. $\S 8-105(4)(\mathrm{b})$.

$265 \S 8$ 8-105(4)(a); BLOOMBERG \& GATLING, supra note 262, at 10.

266 Id.

267 Id.

268 Id.

269 Lozner, supra note 80, at 796. 
ability to gather evidence and build strong cases. ${ }^{270}$ This approach is considered the cause of a significant increase in probable cause determinations and resulting settlements and is thus deemed by the City to be a success. ${ }^{271}$ As noted with the San Francisco experiment above, it is substantively impossible to verify whether or not the new approach to alleged human rights violations has been the cause of any improvement. For example, fewer cases regarding citizenship status, disability, sexual orientation, and arrest records were filed in 2011 compared to 2009 , but more cases were filed in relation to age, retaliation, national origin, race, and gender issues. ${ }^{272}$ The number of inquiries followed the same pattern. ${ }^{273}$

\section{Climate Change in New York City: Modeling Local Authority on International Initiatives}

In addition to attempting to alleviate discrimination and other types of human rights violations, New York City is also taking decisive action in the climate change arena. The annual GHG emissions of New York City account for one-sixth of one percent of global emissions; the same amount as the emissions of Switzerland. ${ }^{274}$ The City has thus decided to take relatively aggressive action against climate change, and in 2007 released PlaNYC (PlaNYC or the Plan). ${ }^{275}$ The overall aim of the Plan is to help the City prepare for climate change, prepare for one million more future residents, and to strengthen the City economy. ${ }^{276}$

The climate change goal of PlaNYC is threefold: First, to reduce city wide GHG emissions by more than $30 \%$ below 2005 levels by $2030 ;^{277}$ second, to obtain an $80 \%$ emissions reduction by $2050 ; ;^{278}$ and third, to increase the resilience of the City communities, natural

\footnotetext{
270 Michael R. BloOmberg \& PAtricia L. Gatling, New York City COMMission ON HUMAN RIGHTS: 2011 ANNUAL REPORT 4 (2011), available at http://www.nyc .gov/html/cchr/pdf/annual11.pdf.

271 Id.

272 Id. at 8.

273 Id. at 9.

274 City of New York, PlanyC: A Greener, Greater New York 150 (2011) [hereinafter PLANYC].

275 About PlaNYC, PLANYC, http://www.nyc.gov/html/planyc2030/html/about/about .shtml (last visited Apr. 10, 2013).

276 Id.

277 PLANYC, supra note 274, at 150-51, 155.

278 Id. at 151 . New York State adopted the $80 \%$ goal via Executive Order No. 24 of August 6, 2009.
} 
systems, and infrastructure to climate risks. ${ }^{279}$ To reach the overall goals, the Plan lists thirteen initiatives such as updating Building Code regulations, improving compliance with the City's Energy Code, revising City codes and regulations to reduce construction and demolition waste, and partnering with the Federal Emergency Management Agency (FEMA) to update flood insurance rate maps. ${ }^{280}$ Importantly, the Plan also sets specific benchmarks that a wide range of government departments must meet by 2013 in order to show what progress is made towards the 2030 goal. ${ }^{281}$

Hailed as an "unprecedented effort," PlaNYC was initiated by Mayor Bloomberg and has so far brought together more than twentyfive City agencies to work toward the vision of a greener and better New York. $^{282}$ The City recognizes that implementing the Plan "requires the collective action and resources of city government, the City Council, the State Legislature, state agencies, public authorities, the private and non-profit sectors, and individual New Yorkers."283 No less than seventy public and private parties are listed in connection with the implementation stages of the Plan. ${ }^{284}$ These include community-based organizations, various NGOs, the New York City Law Department, the New York Police Department, the New York Power Authority, and local development corporations, as well as many branches of the city, state and federal governments. ${ }^{285}$

In developing its climate change plan, New York City took supranational inspiration in two ways. First, the City applies the goal of the Intergovernmental Panel on Climate Change's (IPCC) to reduce GHG emissions by $60-80 \%$ below 1990 levels by $2050 .{ }^{286}$ Second, the City directly modeled its New York City Panel on Climate Change (NPCC) on the IPCC. ${ }^{287}$ NPCC consists of leading climate and impact scientists, academics, economists, and risk management, insurance, and legal experts. ${ }^{288}$ NPCC developed the first official climate change projections for New York City as well as

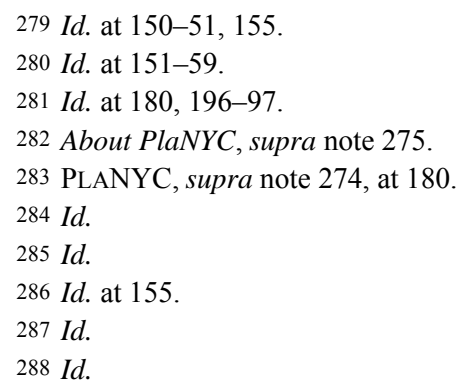


recommendations on how to foster an effective, ongoing, and iterative climate resilience program. ${ }^{289}$ NPCC is to become fully institutionalized ${ }^{290}$ to curtail the risk of discontinuation by future city leadership.

The New York City climate change initiative demonstrates two important lessons: Local authorities often discuss working across sectors and with civil society in achieving legally binding goals and other important benchmarks. New York City is currently actively doing so. It is thus possible for local actors to not only "talk the talk," but also to be able to "walk the walk" given the requisite initial government willingness at the decision-making level. Further, whereas many other actors may at least officially shy away from associating with United Nations bodies, however loosely, New York City has demonstrated that international efforts including those of the UN can and do lead to locally similar authority and on-the-ground action.

\section{Denver: Practical Lessons in Public Participation}

Denver's experiences so far with climate change action are illustrative, although not so much so because of the City's actual substantive provisions or possible emissions reduction results at this stage. Rather, Denver's climate change agreement calls for a significant amount of public participation, including contributions by private experts. Although this would normally be a boon to the local community, the Denver experiment also demonstrates a pitfall in the use of public participation from which other implementers of public participation can learn.

In 2005, the City of Denver conducted a footprint assessment and found that carbon emissions were increasing in direct proportion to the population growth. ${ }^{291}$ That same year, Mayor Hickenlooper was one of the first forty-nine mayors to sign the United States Mayors' Climate Protection Agreement (MCPA). ${ }^{292}$ The Mayor also created "Greenprint Denver," Denver's general action plan for sustainability, and appointed a group of thirty-three civil, business, and government

\footnotetext{
289 Id.

290 Id.

291 Q\&A with Greenprint Denver Director Michele Weingarden, DENVER.ORG, http://www.denver.org/metro/features/greenprint-denver (last visited Apr. 10, 2013) [hereinafter $Q \& A]$.

292 Id. For more details on the MCPA, see the author's parallel project on this and other subnational climate change experiments.
} 
leaders to form the Denver Greenprint Advisory Council (Advisory Council). ${ }^{293}$ The Advisory Council works with scientists and policymakers to gain an understanding of the issues and opportunities faced by the City and to study best climate change practices from around the nation. ${ }^{294}$ The Advisory Council prepared the City of Denver Climate Action Plan (Action Plan), which the mayor signed in $2007 .^{295}$

At that time, Denver's climate change reduction goal was to reach $10 \%$ per capita GHG reductions by $2012 .{ }^{296}$ Since the adoption of the Action Plan, a 2008 study showed that the American West is warming $70 \%$ faster than the planet as a whole, and that the most significant temperature increase within the West is in the Colorado River Basin. ${ }^{297}$ As a long-term goal, the Advisory Council has thus since recommended that the City adopt an absolute reduction target of $25 \%$ by 2020 to bring the entire Denver community below 1990 levels. ${ }^{298}$ Further, the Advisory Council has recommended that "sufficient time" be allowed for actions such as green market development, building upgrades, and retrofitting, and that future plans should look twenty-plus years ahead of their development. ${ }^{299}$

The ten primary strategies that Denver plans to undertake to reach these goals are as follows: to develop major business and residential outreach campaigns; incentivize energy conservation; to create a voluntary travel offset program; for the City to lead by example when it comes to energy use at the City airport, in the City buildings, and by the City fleet; to enhance recycling; to create mandatory energy efficiency standards for new and remodeled buildings; to create incentives for increasing energy efficiency in existing homes; to create a community-wide high-performing "Green Concrete Policy"

\footnotetext{
293 Id.

294 Mayor's Greenprint Denver Advisory Panel, City of Denver Climate ACTION PLAN: FinAL RECOMMENDATIONS TO MAYOR HiCKENLOOPER 3 (2007), available at http://www.greenprintdenver.org/docs/DenverClimateActionPlan.pdf [hereinafter DENVER CLIMATE ACTION PLAN]; Q\&A, supra note 291.

295 Q\&A, supra note 291.

296 Id. The MCPA goal was to "meet or beat" the Kyoto Protocol target for the United States, which was to reduce GHGs by 7\% from 1990 levels by 2012. See also U.S. Conference of Mayors Climate Protection Agreement, MAYORS Climate PROTECTION CENTER (2008), http://www.usmayors.org/climateprotection/agreement.htm [hereinafter U.S. Conference of Mayors].

297 DenVer Climate ACTION Plan, supra note 294, at 3.

298 Id. at 4.

299 Id. at 38.
} 
which would require the use of "green concrete" (i.e., with fly ash) in all private and public construction projects; to establish a compact growth boundary with incentives for density in urban areas; and to render City support for alternative transportation strategies. ${ }^{300}$ Of these, only the energy efficiency standards for new and remodeled buildings, the Green Concrete Policy, and the compact growth boundary appear to be mandatory. In other words, only three out of ten steps are legally binding. For those wishing to see new climate change law with significant "teeth," Denver may thus not be the best example. However, mandatory provisions are not the only-or even the best-solution to climate change issues. "Soft" incentives and plans may in certain contexts and locales prove to be just as or more efficient.

Substantively, neither the City of Denver nor the website of the U.S. Conference of Mayors Climate Change Agreement indicate that the city was able to reach the modest goal of reducing emissions by $10 \%$ by the end of $2012 .{ }^{301}$ Had the cities and regions been able to create substantively significant results, these would undoubtedly have been widely publicized. This is disappointing given the initially indicated interest in climate mitigation at this scale. Hopefully, city and regional efforts to reach the necessary substantive climate change goals will be stepped up to match the initially indicated interest levels. One may suspect that some of the initial promises were of a more promotional than sincere nature.

As regards procedural results, at least one scholar argues that the only way of truly measuring "success" in the climate change area is to analyze whether or not the measures taken to reduce GHGs included public participation provisions; in other words, to examine only the procedural, but not the substantive aspects of the various measures. ${ }^{302}$ Under this theory, the legal, technical, and scientific complexities of climate change make it impossible to trace any positive or negative effects to any particular substantive measure taken. ${ }^{303}$ Accordingly, any substantively positive result could just as well have been caused by one measure as the other. This Article and the author's parallel project examining the possible effects of select sub-national climate change experiments take a differing view. While it is, of course, true that climate change is a highly complex problem, many other severe

\footnotetext{
300 Id. at 18.

301 U.S. Conference of Mayors, supra note 296.

302 Sampaio, supra note 95, at 357.

303 Id.
} 
societal problems have been as well. This has not been and should not be grounds for researchers and policymakers to give up attempts to verify any possible substantive effects of the mechanisms we study. Such an attitude would not only be defeatist, but also serve little practical purpose. In order to proceed with possible solutions to pressing societal problems, we will have to at least attempt to trace positive substantive results to their possible root causes for reinforcement and future replication. Refraining from verifying any possible substantive effects of various measures serves little theoretical or practical purpose. For example, if patterns appear across a range of climate change reduction experiments that eventually lead to, for example, actual GHG reductions, this would give us good cause to further consider whether the substantively common provisions of such experiments might be more effective than others. Granted, this is neither easy work nor work that leaves all questions related to causes and effects unanswered, but must be attempted nonetheless.

To be sure, the procedural aspect of the Denver experience illustrates how public participation can be used in fruitful ways, but how it can also, without sufficient cautionary steps being taken, lead to unfortunate results. Positively, the development of the Denver Climate Action Plan included a wide range of civil society participants. Before making any final recommendations, the Advisory Council hosted several public forums and participated in events with more than 300 people present. ${ }^{304}$ Comments on the proposed Plan were solicited via a weblog, as well as through email and other writings. ${ }^{305}$ The Council itself consists of three dozen business, civic, and community leaders joined by managers of several City departments as well as experts from the University of Colorado at Denver. $^{306}$

The Climate Action Plan (Plan) also comprises several aspects of public participation. One of the Plan's guiding principles is to

304 Letter from Greenpoint Denver Advisory Council to Mayor Hickenlooper (Oct. 2007), in DENVER CliMATE ACTION PlAN, supra note 294.

305 Id.

306 Letter from Greenpoint Denver Advisory Council Accompanying the Original Draft Climate Action Plan to Mayor Hickenlooper (May 2007), in DenVer Climate ACTION PLAN, supra note 294. Examples include representatives from financial companies; energy corporations; youth groups; museums; the Denver Public School system; the Colorado Environment Coalition and other non-profits; architects; neighborhood liaison contact persons; a bank; as well as City and County members and City staff. Id. at 1. 
"partner with community organizations, cultural institutions and businesses to achieve broad impact." 307 Among the first listed recommendations for implementation of the Plan is to "[d]evelop major business and residential outreach campaigns." 308 The nonprofit members of the Council are responsible for reaching out to Denver's residents in an attempt to "nudge" them to live more sustainably. ${ }^{309}$ For example, the "Take 5 Pledge" helps residents reduce their community's energy use, water use, waste, air pollution, and improve Denver's land. ${ }^{310}$

Recognizing the importance of communications and of imparting a favorable opinion about the Denver climate change efforts to the general public and its involvement in the climate change process, Denver has officially adopted "social marketing" as its public engagement strategy: "Social marketing is a term used to describe non-traditional strategies that focus on changing behaviors. Widespread research confirms the effectiveness of social marketing tools to engage individuals and groups in improving their own lives and their communities." 311 The target audiences of this "marketing" campaign are businesses, neighborhoods, and youth, including several subgroups under each category, such as cabdrivers under the business category. ${ }^{312}$ Parties promoting climate change action would be well advised to take note of the importance of correct communication. For example, it may not be wise to continue the "Sky is Falling" rhetoric so often used in initial climate change discourse. It may be wiser to adopt a more practical and less fatalistic communication strategy that can once again engage the general citizenry and thus law and policy makers in true progress.

Denver's steps to incorporate public participation in its governance models are positive, just as its modern communication strategy sets an important example for other authorities to consider. Unfortunately, the Denver experiment also shows how taking the opinions of a too narrow range of community members into account may lead to

\footnotetext{
307 Mission and Guiding Principles, GREENPRINT DENVER, http://www.greenprint denver.org/about/mission-and-guiding-principles/ (last visited Apr. 10, 2013).

308 DenVer Climate ACtion Plan, supra note 294, at 5.

309 Q\&A, supra note 291. For more information on the "nudge" theory, which in recent scholarship has been described as important in making private individuals take more steps in the right direction both when it comes to climate change and other important issues, see the author's parallel project on climate change experiments.

310 Id.

311 DenVer Climate ACtion Plan, supra note 294, at 37.

312 Id.
} 
socially inopportune and skewed results. The input process needs to be balanced to lead to socially fair results. In the "Five Points" area of Denver, luxury lofts and new housing developments were built taking both the environment and public opinion into account. ${ }^{313}$ However, the area had been one of few predominantly African American-owned commercial strips in the country, and that segment of the community was virtually left out of the policymaking process. ${ }^{314}$ The development model followed by the "Five Points" initiative removed older buildings in economically struggling neighborhoods to make way for newer, more "attractive"-but also often more expensivedevelopments. ${ }^{315}$ Some of the buildings removed presented the mere risk of lowering the property values of the newer developments, but formed part of old established and traditionally African American communities. ${ }^{316}$ After this gentrification process, the Five Points community is now much less African American and much more white and Hispanic than before. ${ }^{317}$ This result is somewhat surprising given Executive Order \# 123, which calls for City officials to "[e]nsure that all City and program decisions incorporate [a] 'triple bottom line' analysis, balancing ... social[] and environmental considerations." 318 The Five Point project has thus raised environmental and social justice concerns that could have been better addressed by ensuring that the voice of the local community members was heard and duly taken into account before the development was completed. In other words, the project failed both procedurally and substantively seen from the African American community's point of view. The Five Point experience could even be said to present human rights implications. This is so because modernly, human rights - in addition to environmental concerns-cover the freedom from arbitrary interference in privacy or family life as well as the right to property. Both rights were arguably violated in Denver. Other cities and regions should remember to apply public participation provisions in their decision-making processes in more socially balanced ways.

313 Sampaio, supra note 95, at 379-80.

314 Id. at 379.

315 Colleen O'Connor, A Makeover for Five Points, DENVER POST, Nov. 23, 2011, http://www.denverost.com/ci_16688201.

316 Sampaio, supra note 95 , at 380.

317 Id. at $379-80$

318 Mayor John W. Hickenlooper, Exec. Order No. 123, 2 (Dec. 17, 2010), available at http://www.greenprintdenver.org/docs/CCDXO123.pdf (emphasis added). 


\section{E. Santa Fe: Interweaving Sustainability with Principles of Economic Health and Social Justice}

Santa Fe, New Mexico undertook to reduce its GHG emissions by $7 \%$ by 2012 in $2008 .{ }^{319}$ Subsequently, Santa Fe adopted the Mayor's Climate Protection Agreement "2030 Challenge" under which the city seeks to reduce its fossil fuel energy consumption by $70 \%$ by 2015 and to become carbon neutral by $2030 .{ }^{320}$ Although the latter is substantively impressive, what makes the Santa Fe plan interesting for purposes of this Article is how the city has broadened its view of the sustainability challenges to be solved in the near and far future. The "Sustainable Santa Fe Plan" does not approach the issues to be solved separately via a veritable "to do list" as many other cities do. Rather, the city recognizes that sustainability "also can be defined as the intersection between three principals [sic]; environmental stewardship, economic health; and social justice.",321

This plan addresses more than just greenhouse gas emissions. It looks to the history and culture of Santa Fe and incorporates other values of this community. By doing this, it takes a plan that would normally have a single focus and uses it as a catalyst to promote "community sustainability" by also considering other social and economic goals. It attempts to distribute the benefits and costs of moving towards sustainability in an equitable way. ${ }^{322}$

Exactly how does Santa Fe plan to implement this more equitable approach? A city official explains that the three areas are meant to pose guidelines for the City to follow, and gives as examples of actually implemented action the following: ${ }^{323}$ the City and County Food Policy Advisory Council includes directors of several food providers for food-insecure residents. The Council is developing policies and partnerships to reduce risks of food insecurity resulting from climate change and peak oil prices. The City has undertaken an extensive bilingual community outreach process for input on how to

319 Guiding Principles, Sustainable Santa Fe Plan: Building a More SUSTAINABLE FUTURE BY LOOKING TO THE PAST (Oct. 29, 2008), available at http://www.santafenm.gov/DocumentCenter/Home/View/702. Santa Fe is a member of the MCPA.

320 City of SANTA Fe, N.M., Resolution No. 2009-100, available at http://www .santafenm.gov/archives/168/2009-100.pdf; The 2030 Challenge, ARCHITECTURE 2030 (2011), http://architecture2030.org/2030_challenge/the_2030_challenge.

321 Introduction and Approach, SANTA FE 400, http://www.santafenm.gov/ index.aspx?NID=1372 (last visited Apr. 24, 2013).

322 Id.

323 Telephone Interview with Katherine Mortimer, Sustainable Santa Fe Programs Manager (Aug. 16, 2012) (notes on file with the author). 
use land use regulations and public investments to improve the health outcomes of the poorest areas of the community. In cooperation with a local non-profit organization, the City has also funded a low-interest loan program for energy efficiency and solar energy improvements for income-qualified homeowners. Further, the City makes use of an aggressive building code for residences. In developing this, the City worked with the non-profit organizations Homewise and Habitat for Humanity to ensure that the code would not result in a net increase of home prices. This has been accomplished because, among other things, investment costs are offset by energy savings. In fact, the code has facilitated lower out-of-pocket expenses for homes smaller than 3,000 square feet (typically, low-income persons do not live in homes larger than that). Homes larger than 3,000 square feet have to comply with more strict energy efficiency requirements. The City official notes that these steps have been universally accepted by civil society in Santa Fe, which prides itself on being a socially progressive city in general. ${ }^{324}$ Finally, fiscal impact reports must be prepared in relation to any measures taken by the City. Accordingly, the Santa Fe Building Code was developed with the active assistance of a range of parties such as a homebuilders association, realtors, suppliers, Habitat for Humanity, and Homewise. These market actors and specialists in each their own area responded to the City's need to find out what made the most economic sense, but also what steps would embrace the three sustainability issues before the Code was developed.

The Santa Fe example demonstrates the level of cooperation that can, with appropriate planning and government mandates, be established among private and public actors. Perhaps more importantly, the example shows how modern governance models can actively promote synergism between environmental, social, and economic issues. It also shows how cities can produce more longterm viable results for a wider segment of society by taking a step back from yesterday's more narrow focus on one-track solutions. A broader view of development and sustainability presents greater

\footnotetext{
324 Id. In many areas of the nation, homes larger than 3000 square feet would be considered very large and thus probably more likely to be purchased by well-to-do individuals whereas poorer individuals may not be able to afford homes of that much square footage. To the extent that most residents of Santa Fe consider it fair that people who are more financially secure than others face stricter and perhaps more expensive environmental regulations, this could explain the fact that this particular requirement is "universally accepted" in Santa Fe. The author's phone interview with Ms. Mortimer did not go into detail with this.
} 
potential for equitable approaches. In short, the Santa Fe example possesses interesting potential that should be followed in future scholarship.

\section{F. London: New Frameworks for Climate Change and Public Participation}

In contrast to cities in the United States, London operates under a triple set of rules governing climate change: city, national, and EU law. To better understand the city rules and general attitude towards climate change mandates in London, a brief introduction to the overarching EU and national rules is helpful before proceeding with the London example in particular.

Whereas federal climate change is more marked by inaction than action in the United States, the situation in the United Kingdom (and thus London) is more promising. First, the United Kingdom Climate Change Act of 2008 set the statutory target of $\mathrm{CO}_{2}$ emissions reductions to at least $80 \%$ below 1990 levels by 2050 with an interim target of $34 \%$ by $2020 .{ }^{325}$ The latter goes even further than the EU's " 20 by 20 " goal whereby the EU has committed to reduce regional GHG emissions by $20 \%$ over 1990 levels by $2020 .{ }^{326}$ Additionally, the Renewable Energy Directive of 2009 calls for the United Kingdom to source $15 \%$ of its energy from renewable sources by 2020, almost a seven-fold increase from 2008 in little more than a decade. $^{327}$

Second, the United Kingdom has adopted several Acts, the goal of which are to empower local governments to reach climate change and general sustainability goals while taking the triad of bottom-up law development, public participation, and overall social "well-being" into account. For example, the Localism Act of 2011 imposes a specific "duty to cooperate" on the mayor of London, the relatively new Greater London Authority (GLA), and the thirty-three London boroughs. ${ }^{328}$ The Localism Act signals a major shift of responsibilities

325 Planning \& Climate Change Coalition, Planning for Climate ChangeGUIDANCE FOR LOCAL AUTHORITIES 5 (Apr. 2012), available at http://www.tcpa.org.uk /data/files/PCC_Guide_April_2012.pdf.

326 What is the EU Doing About Climate Change?, EUROPEAN COMMISSION: CliMATE ACTION, http://ec.europa.eu/clima/policies/brief/eu/index_en.htm (last updated Jan. 7, 2013). The EU has further committed to reducing its GHG emissions by $80-95 \%$ compared to 1990 levels by 2050 . Id.

327 Planning \& Climate Change Coalition, supra note 325 , at 5.

328 London and the Localism Act, FUTURE OF LONDON (Dec. 13, 2011), http://www.futureoflondon.org.uk/2011/12/13/london-and-the-localism-act/. 
to local authority and community levels in England. ${ }^{329}$ It also creates a platform for traditional local authorities, other public bodies, Local Enterprise Partnerships (officially recognized partnerships between local authorities and businesses), and Local Nature Partnerships (government partnerships with environmental organizations) to work together locally on the sustainable development of land. ${ }^{330}$ Individual think tanks such as the Planning and Climate Change Coalition support government planning efforts under the Localism Act in an attempt to ensure that the planning system responds effectively to the climate challenge. ${ }^{331}$

Another innovative step that seeks to take multi-level governance in the U.K. in a new direction is the Local Government Act of 2000, which introduces a specific "duty of well-being." In pertinent part, the Act empowers local authorities as follows:

Every local authority are to have power to do anything which they consider is likely to achieve any one or more of the following objects-

(a) the promotion or improvement of the economic well-being of their area,

(b) the promotion or improvement of the social well-being of their area, and

(c) the promotion or improvement of the environmental well-being of their area.

This broad power enables eligible government bodies to do

anything which they consider is likely to achieve the promotion or improvement of the economic, social or environmental well-being of their area. The [national] Government's purpose in extending the well-being power to eligible councils is to give communities greater flexibility to act on their priorities and to facilitate joint working between local councils and their partners in the private and public sector.

329 Planning \& Climate Change CoAlition, supra note 325 , at 2.

330 Id. at $2,5$.

331 Id. at 2. This Coalition is supported by, among many others, one city council, a university, energy foundations, building associations, nature organizations, and other nonprofits. It has "no core funding and no political or corporate affiliations." Id.

332 Local Government Act 2000, c. 22, § 2(1)(a)-(c) (Eng.), available at http://www .legislation.gov.uk/ukpga/2000/22/pdfs/ukpga_20000022_en.pdf.

333 DeP'T For CMTYS. \& LOCAl GOV'T, Power to PROMOte Well-Being of THE AREA: StATUTORY GUIDANCE FOR LOCAL COUNCILS 3 (Feb. 2009), available at https://www.gov.uk/government/uploads/system/uploads/attachment_data/file/8335/11488 97.pdf (emphasis added). 
The breadth of the power removes the need for local councils to rely on other legislation in order to take particular action. Instead, local councils can look to the well-being power in the first instance. In other words, they can regard it as a "power of first resort," albeit still one featuring various built-in safeguards. ${ }^{334}$

Some government bodies have employed this authority to address climate change. ${ }^{335}$ Although local authorities receive both guidance and national performance indicators from the national government, there is no statutory responsibility to follow such guidance. ${ }^{336}$ This has broadened the scope for local governments to act on climate change through individually preferable means and led to a greater level of involvement by local authorities than was the case in the late 1990s. ${ }^{337}$ The new power has thus enabled local authorities "to move away from their necessarily cautious approach to innovation and joint action which had previously limited their contribution to the improvement of the quality of life of their communities." ${ }^{\text {,38 }}$ Finally, the national government has adopted affirmative steps to remove legislative barriers that stand in the way of government efficiency. ${ }^{339}$

In London proper, several new local governance developments also stand out in relation to climate change. In 2004, the impetus for local climate change action in London came directly from the Mayor who, without having any direct statutory authority to do so, developed an energy strategy for London that placed climate center stage. ${ }^{340}$ In addition to its substantive goals, a focal point of this strategy was to emphasize voluntary action through a partnership approach by forming the London Energy Partnership (made up of a consortium of businesses, government and public bodies $)^{341}$ and cooperating with

334 Id. at 3-4, 15. Specific examples of the kind of action an eligible council may take are set out in section 2(4) of the Act. These include, but are not limited to, incurring expenditure; entering into co-operation or partnership arrangements with any person; giving financial assistance; and carrying out the functions of other bodies. Under the Interpretation Act of 1978, a "person" is defined as "corporate or un-incorporate," e.g., individuals and relevant statutory bodies such as police, health and parks authorities, and businesses, voluntary and community groups and other local organizations. Id. at 9.

335 Trisolini, supra note 92, at 866.

336 Id.

337 Id.

338 DEP'T FOR CMTYS. \& LOCAL GOV'T, supra note 333, at 3.

339 Id. at 23.

340 Heike Schroeder \& Harriet Bulkeley, Global Cities \& the Governance of Climate Change: What is the Role of Law in Cities?, 36 FORDHAM URB. L.J. 313, 335 (2009).

341 LONDON ENERGY P'SHIP, http://www.lep.org.uk (last visited Apr. 11, 2013). 

and Human Rights Law from the Bottom Up

two other partnerships. ${ }^{342}$ In 2005, the London Climate Change Agency was established as a municipal company wholly owned and controlled by the London Development Agency, but with significant private and civil sector support from, among other actors, BP, KPMG, the City of London Corporation, Greenpeace, and the Rockefeller Brothers' Trust. ${ }^{343}$ Additionally, the London Climate Change Partnership (LCCP) is an independent group of more than thirty organizations who have an important role to play in trying to do what is locally possible to mitigate climate change, but ultimately also in preparing London for the impacts of climate change. ${ }^{344}$ Among the objectives of the LCCP is to gather and disseminate high quality information to assist in further developments of the London Plan, as well as other strategies and policies that affect London, including by providing key consulting and communication assistance. ${ }^{345}$ General and steering group members include participants from government agencies, private business NGOs, accounting, energy, and development companies as well as climate scientists and communication specialists. ${ }^{346}$

In 2007, the Greater London Authority Act of 2007 (GLA Act) charged the Mayor with the new specific duty of "tak[ing] action with a view to mitigation of, or adaptation to, climate change." $" 347$ The Mayor is now required to produce local statutory strategies for climate change mitigation and adaptation as well as new energy strategies. ${ }^{348}$ Although the London mayor's direct powers are limited compared to similar offices in other world cities, ${ }^{349}$ each individual mayor still has relatively strong powers. ${ }^{350}$ Thus, the GLA Act creates

\footnotetext{
342 Schroeder \& Bulkeley, supra note 340 , at 335.

343 Id. at 336-37.

344 LONDON Climate ChANGe P'ShIP, http://climatelondon.org.uk/lccp/ (last visited Apr. 11, 2013).

345 Id.

346 Id.

347 Greater London Authority Act 2007, ch. 24, § 42 (Eng.), available at http://www .legislation.gov.uk/ukpga/2007/24/pdfs/ukpga_20070024_en.pdf; see also GREATER LONDON AUthority, THE LONDON Plan: SPATIAL DEVElOPMENT STRATEgy FOR GREATER LONDON, CONSOLIDATED WITH ALTERATIONS SinCE 2004195 (2008), available at http://www.london.gov.uk/thelondonplan/docs/londonplan08.pdf.

348 Schroeder \& Bulkeley, supra note 340 , at 338 .

349 Charlotte Streck \& Thiago B. Chagas, The Future of the CDM in a Post-Kyoto World, 1 CARBON \& CLIMATE L. REV. 53, 57 (2007).

350 Planning \& Climate Change Coalition, supra note 325 , at 5, n.9.
} 
an important legal platform that remains as mayors and their political platforms change.

Via the above and other measures, the City addresses sustainability through an updated version of what is known as the "London Plan.",351 This is the "overall strategic plan for London . . . set[ting] out a fully integrated economic, environmental, transport and social framework for the development of the capital to 2031." ${ }^{352}$ The climate change target is to reduce London's $\mathrm{CO}_{2}$ emissions by $60 \%$ of 1990 levels by 2025 and at least $80 \%$ by $2050 .{ }^{353}$ Sections 5.2, 5.5, and 5.7 are considered particularly important in reaching this goal. Section 5.2 sets forth an energy hierarchy that requires the City to " 1 ) [b]e lean: use less energy; 2) [b]e clean: supply energy efficiently; [and] 3) [b]e green: use renewable energy." "354 ("Lean, clean, green"). Section 5.5 requires $25 \%$ of the heat and power used in London to be generated through use of localized decentralized heating systems by 2025 . Section 5.7 increases the proportion of energy generated from renewable sources.

The renewed London Plan is noteworthy because of the extent to which public participation informed the development of the climate change policies. A Senior Strategic Planner from the GLA explains:

Shortly after his election, the current Mayor consulted on his 'Planning for a better London' in July 2008. This led to a full review of the London Plan. Initial proposals were published in his document 'A new Plan for London' in April 2009-formally for consultation with the London Assembly and the GLA functional bodies although comments were invited from anyone wished to give them. Both these documents included sustainability and climate change elements relating to development. The draft climate change policies were initially developed with the help of colleagues in the Greater London Authority and other organisations that we work with such as the LUCID programme (The Development of Local Urban Climatic Model and its application to Intelligent Design of Cities). The draft replacement London Plan was [subsequently] published for full public consultation ... The development of the London Plan is informed by an Integrated Impact Assessment (IIA) as required by national and European legislation. The IIA aims to

351 The London Plan, GREATER LONDON AUTHORITY, http://www.london.gov.uk /priorities/planning/londonplan (last visited Apr. 11, 2013).

352 Id.

353 Energy Planning: Monitoring the Impact of London Plan Energy POLICIES IN 2010, EXECUTIVE SUMMARY 4 (Oct. 2011), available at http://www.london .gov.uk/sites/default/files/monitoring_impact_london_plan_energy_policies.pdf [hereinafter EXECUTIVE SUMMARY].

354 The London Plan 2011: LONDON's Response to Climate Change 141 (2011), available at http://www.london.gov.uk/sites/default/files/LP2011\%20Chapter\%205.pdf. 

and Human Rights Law from the Bottom Up

assess the potential social (including health and crime), economic and environmental impacts of the proposed plan. To inform the IIA, meetings and workshops were held with internal and external stakeholders, including with those with expert knowledge on sustainability and climate change. Relevant comments from the public consultation and the IIA process were reflected in the version of the draft replacement Plan that was submitted to the Planning Inspectorate for the Examination in Public. During the EiP selected stakeholders were invited to discuss and provide evidence on the proposed policies. The climate change policies were covered by this process. Therefore, there have been numerous opportunities for public input into the development of the climate change policies in the [updated] London Plan.

The London Plan is also noteworthy because it is legally binding. The Mayor must work with boroughs and developers to ensure that all City developments meet the targets set forth in the Plan. ${ }^{356}$ This is implemented as follows: ${ }^{357}$ all developments referred to the Mayor for his approval are to be accompanied by an Energy Assessment demonstrating how the energy hierarchy and targets set out in London Plan policy 5.2 have been addressed and met. Experts then review the Assessment to ensure that the methodology is appropriate. If the targets are not met, negotiations will be undertaken in an attempt to make sure that they are. In complex situations, section 5.2 compliance will be assessed along with other policy objectives. Where a solution cannot be met, a contribution towards offsetting carbon emissions elsewhere in the local area is sought. The proposals set out in the Energy Assessment can also be secured by way of a condition on the planning approval or through a "s106 planning obligation," which is a legal agreement entered into by the developer. Financial contributions can be secured through s106 obligations. Compliance and enforcement issues are dealt with by the local planning authorities, who are responsible for implementing the Plan at local level. Finally, some boroughs seek annual energy statements from developments to ensure compliance.

Identifying the exact original drivers of climate change action in London is complex, but can in large part be traced back to the strong original interest level of a keenly interested mayor, added to over time by support from the local and national governments. The current

355 E-mail from Celeste Giusti, Senior Strategic Planner, London Plan Team, Greater London Authority (Sept. 3, 2012) (on file with author).

356 E-mail from Celeste Giusti, Senior Strategic Planner, London Plan Team, Greater London Authority (Aug. 15, 2012) (on file with author).

357 Id. 
impetus consists of the commitments of not only the Mayor, but also key individuals and interest groups, a generally positive climate of public opinion towards climate change alleviation, a lack of overt opposition from key interest groups and the emergence of new market opportunities. $^{358}$

Pinpointing the authorities overseeing climate change action is equally complex. On the one hand, the central government directs the local government via, for example, performance indicators; but on the other hand, considerable scope for local government to act through individually chosen means still exists, as shown above. ${ }^{359}$ This situation is somewhat different from that of U.S. cities which, because they enjoy no direct recognition in the Constitution, are mere conveniences of each state and thus have more limited original powers.

In addition to ensuring the procedurally sound method of public participation in both information-gathering and policy-making, what are some possible substantive results achieved in London? Substantial $\mathrm{CO}_{2}$ savings were secured through implementation of the London Plan in 2010, at least in the building sector. ${ }^{360}$ For example, London achieved an average $\mathrm{CO}_{2}$ savings of $33 \%$ per building development over and above a 2006 baseline development including unregulated energy. ${ }^{361}$ London also saw a reduction of approximately $50 \%$ in regulated $\mathrm{CO}_{2}$ emissions beyond the minimum requirements contained in the 2006 building regulations. ${ }^{362}$ Overall, in 2010, projected annual $\mathrm{CO}_{2}$ savings of almost 72,000 tonnes of $\mathrm{CO}_{2}$ were secured, which is the same as retrofitting cavity wall insulation in approximately 111,000 existing homes. ${ }^{363}$ However, the largest $\mathrm{CO}_{2}$ reductions were due to energy efficiency and combined heat and power developments with only a smaller amount of energy saving$3 \%$ - due to renewable energy. ${ }^{364}$

So far, the London experiment is thus arguably both procedurally and substantively more successful than comparable U.S. solutions. Public participation and cross-competence governance is as important in London as ever. Sustainability remains key. Of course, this may in

\footnotetext{
358 Schroeder \& Bulkeley, supra note 340 , at 338 .

359 Id. at 334.

360 EXECUTIVE SUMMARY, supra note 353 , at 4.

361 Id.

362 Id.

363 Id. at 5.

364 Id.
} 
large part be due to a national legislative climate that is more conducive to sustainability issues per se, but which also focuses a great deal more on localism and enforced cooperative public-private governance than is the case in the United States. The mandate for local authorities to ensure economic, social, and environmental wellbeing is, to be sure, progressive governance. So is the government's willingness to take active steps to remove legislative barriers that may stand in the way of environmentally and socially sound developments. Similarly, the new duty placed upon the City of London to take affirmative action against climate change, in combination with the City's own interest in doing so, are different from what often seems to be mere indications of hope for long-term change or mere empty rhetoric in the United States. In other words, the official government stance towards climate change in London and the United Kingdom at large is more favorable towards taking broad and deep action at several levels. This may, of course, stem not so much from intrinsic government motivation, but rather from the public opinion towards climate change in the United Kingdom having evolved more than is yet to be seen in the United States. Further, the rhetorical and practical environment in the United Kingdom has not been one in which strong interest groups have demonstrated marked opposition towards climate change, as has been the case in the United States. Additionally, British corporate life has demonstrated a greater interest in the new business opportunities presented by climate regulations, which is different from the situation in the United States. In spite of such differences, valuable lessons can be learned from the London experiences. These can be applied not only to environmental law as it intersects with human rights issues, but also to developments within human rights separate from environmental issues. Similarly, the legal community can learn much from the American developments within both human rights and climate change. These lessons will be illustrated next.

\section{VI \\ LESSONS LEARNED}

New and relatively untraditional action is needed to solve pressing matters within environmental and human rights in a timely manner. Waiting for action from the top down has proved largely unviable, especially in relation to urgent matters such as climate change and other environmental human rights. Drawing together the experiences from the five city experiments analyzed above, this section will 
produce a set of guidelines for future work in this area. Much of the knowledge gained is also applicable to other areas of the law than just human rights, environmental law, or the combination thereof. The most important insights relate to the development of new law, the substance of such law, and the implementation and enforcement of law. This section will proceed in that order.

\section{A. Development of the Law}

Often, the law is framed in negative terms stating what we can, but more often what we cannot, do. It places limits on us, but often does not set forth specific goals as to what should be accomplished with the law in question. It helps to go beyond a negative rights framework by adopting a positive rights approach, which was done in San Francisco. In such an approach, both the rights of and aspirational goals for the intended segment of society are specifically described. A positive rights approach also places specific, affirmative obligations on the implementing actors. ${ }^{365}$ Adopting such a framework may require re-conceptualizing negative paradigms ${ }^{366}$-for example, "antidiscrimination"-into more positive terms and goals, such as those contained in human rights instruments. This was done in San Francisco and presents equally effective potential for other locales and areas of the law. The British climate change experience also exemplifies how modern governments can, with good results, set positive goals, such as creating social, economic, and environmental "well-being." Although this may at first blush appear to be an impossibly broad mandate, the London experience shows how local implementing bodies can at the same time be given equally broad powers to do almost "anything" required to reach the substantive goals. In short a shift from the negative to the positive may be expedient.

Second, inspiration from international instruments and action can inspire and inform local legal developments. Obtaining inspiration from international sources allows us to learn valuable lessons from an even wider range of experiments than just national ones and avoid the waste of precious time by having to reinvent the proverbial wheel. As many legal issues transcend national borders, this is, of course, a plus. But the ideal model for the development of the most effective law seen from a local point of view is actually a hybrid model: one that is

365 Powell, supra note 98 , at 379 .

366 Id. 
not wholly international, but also not wholly national. ${ }^{367}$ Simply put, hybrid models present the best of both worlds. Perhaps more importantly in U.S. society, they are advantageous because of the "foreignness" with which many Americans associate international law. ${ }^{368}$ Whereas it may be difficult to generate broad civil society acceptance of laws that may be seen as "foreign" or internationally sourced, it will be easier to do so if the law in question is developed to feature localized input as well. Localized law is, of course, also substantively better. Further, it may be easier to build momentum towards the eventual national ratification of a possible international instrument such as a particular treaty that inspired local action if civil society and our elected representatives first become acquainted with localized versions of such international initiatives. ${ }^{369}$ The San Francisco model showed a clear example of how law can be developed from the bottom up with clear international inspiration. The New York climate change model also draws on some of the best practices from international models.

The New York human rights model further shows the importance of not merely emulating experiences gained elsewhere, but of localizing frameworks to match local preferences. New York places a much heavier emphasis on traditional law enforcement than San Francisco's more cooperative human rights law enforcement approach. For the reasons described above, it is difficult, if not impossible, to identify which is the "better" of the two approaches; both arguably work well. Nonetheless, scholarship tends to point towards the collaborative approach as presenting new and very expedient options that may be well pursuing at local level just as this approach is used in many international instruments. In contrast, New York appears to be a city in which constituents prefer "strong" and more traditional action. It is important to take such local preferences into account when designing new legal models.

Both the New York human rights and the London climate change models show the decisive action that can be taken when cities have mayors willing to take swift and decisive action. However, this leads to the related concern that mayors are, after all, just temporary actors. Subsequent administrations can wipe out much positive action initiated at the mayoral level unless this becomes institutionalized

367 Id. at 382.

368 Id.

369 Id. 
when created. Thus, when potential new government agencies and programs are created, it is important that these are chartered and thus do not exist only at the pleasure of the mayor. This would ensure that challenges to their existence would have to be given out to referendum in turn making new programs more stable and less vulnerable to the whims of future government entities. ${ }^{370}$

All the above experiments also showed that iterative, adjustable processes are important to the development of new legal models. Law development is not and should not be static; it should be an ongoing, flexible process that can accommodate new developments and knowledge within law, science, and other relevant bodies of knowledge as it appears. This is of particular importance to climate change, where science is evolving more rapidly than what the law has been able to keep up with so far. For example, the Kyoto Protocol initially mandated GHG emissions reductions of a mere 5\%. It has since become clear that this goal is woefully insufficient. Of course, this should be seen in the context of the difficulty of getting a large amount of nations to sign on to any legally binding agreement regarding what was then a problem of relatively newly discovered significance. To be sure, "baby steps" are important to the development of both national and international law, but so is the ability to adjust legal requirements as scientific and other knowledge evolves. Authorities still have much to learn in this respect: only $70 \%$ of the sustainability plans examined in one body of scholarship placed emphasis on the continuous monitoring, evaluation, and updating of the plans. ${ }^{371}$ This percentage should be increased.

Although none of the experiments analyzed above clearly reference non-Western normative ideals, or perhaps exactly because of this, it is relevant to remember the importance of avoiding an exclusive emphasis on "narcissist law," i.e., law that leans more or less exclusively on Western ideals. Non-Western ideals of how law and society should develop may, of course, be applicable and beneficial to Western legal systems as well. Such ideals are finally working their way into legal discourse, such as that produced by at least one prominent ICJ justice. ${ }^{372}$ Non-Western traditions and thinking are of obvious relevance to not only international law, but also various aspects of national substantive law in an increasingly international society. Philosophies regarding, for example, who the law seeks to

370 Lozner, supra note 80 , at 797-98.

371 Arnold, supra note 90, at 859.

372 Former ICJ Justice Christopher Gregory Weeramantry; see supra note 51. 

and Human Rights Law from the Bottom Up

protect; who the law should seek to protect; why; and how, may be particularly relevant to the two substantive legal areas that form the topic for this Article. Such thinking should be considered in future lawmaking in these and other areas.

Public participation at the law development stage has numerous recognized advantages and is implemented more and more frequently both in the United States and beyond. For example, the San Francisco, Denver, Santa Fe, London, and New York climate change developments all feature provisions for extensive civil society involvement and public/private partnerships. Some of the cities analyzed also require broader cross-sector government engagement and, as shown in London, even a specific duty to cooperate across sectors. Such expanded involvement of not only civil society, but better cooperation by relevant government actors is a procedurally sound method of law development. In contrast, the New York human rights model does not feature very noteworthy public participation. Because of this, it may be seen as less "successful," at least from a procedural point of view.

Instead of seeing legal developments from a binary "top-down" or "bottom-up" perspective, some scholars apply a four-faceted model. This is worth considering briefly as it sheds further light on the value of what this Article refers to as bottom-up models and the value of these to future governance. The four-prong model asks whether governance is performed under a "self-governing model," a "control and compliance model," a "provision model," or an "enabling model." "373 First, the "control and compliance" model is most closely related to the traditional development of law. As binding mandates are being set from a higher authority that also verifies compliance and enforces observance, this model compares to a top-down solution. The control and compliance model is used in those aspects of the London sustainability framework where standards are being set by the central government and the EU, but where the Mayor subsequently creates local mandates for sustainable energy use. Perhaps because it is a top-down model, much of the London Plan met with significant challenges from the business community in London in the form of contestation over the rights and responsibilities of different actors. ${ }^{374}$ Nonetheless, the model is important, as national or supranational impetus is still important in shaping possibilities for local action. This

373 Schroeder \& Bulkeley, supra note 340 , at 351-58.

374 Id. at $353-54$. 
model uses already existing legal framework and modalities. Civil society will thus have a great deal of familiarity with governance through this model, for better or worse. Importantly, it enables multilevel governance, which is important to many aspects of the law, such as the development of building codes, which must often meet national standards but are implemented and enforced locally.

The "self-governing" model compares to a pure bottom-up model. Under this, authorities take voluntary action to reach their goals without specific directives from above. This was the case with some of the London, San Francisco, Denver, and Santa Fe action, but is not yet the most predominant governance model on a broader scale. A mixture of self-governance and national impetus is more realistic at this point in time.

The "provision" model is another example of a bottom-up model under which utility companies that have not been privatized can, more easily than purely profit-driven private companies, choose to provide society with energy and related solutions that are more sustainable than others - for example, selling a larger-than-before share of renewable energy, providing other energy "services" (e.g., "concierge services" ${ }^{375}$ ), improving water management, etcetera. However, this model is waning because of the large extent to which privatization has already taken place and is still taking place. Nonetheless, where possible, this model is still considered key to environmental law because it enables on-the-ground, swift development of sustainable energy and sets important examples for other utilities to follow.

The "enabling" model is a bottom-up solution with some top-down characteristics. It is considered important to sustainability efforts. Under this, governments "steer" other actors, including those in the voluntary and private sectors and at the community level, to act for the public good. This model includes a large amount of public-private partnerships as well as subsidies and other "soft" incentives for nongovernmental actors to reach particular policy ends. It is a response to "declining formal powers and competencies, a means of getting things done when other channels are blocked." $" 376$ The enabling model is increasingly mandated by central governments and thus shares commonalities with top-down solutions. It is, for example, used in

375 An energy concierge program gives individual or corporate building owners a single point of contact in connection with building improvements rather than having to maneuver between banks, auditors, contractors, and utilities. SightLinE InSTITUTE, What is An Energy Concierge?, http://www.sightline.org/research/energy-concierge/.

376 Schroeder \& Bulkeley, supra note 340, at 356. 
London where governments are now expected to work closely with non-government partners representing both business and purely private interests. In the United States, the closest version of what may be seen as an enabling model is still federal "grant-in-aid" schemes to local governments to enable the implementation of national goals at the local level. Many positive lessons can be learned in the United States and around the world from the London experience about enabling local government to establish better local environments in closer cooperation with the ultimate civil society stakeholders. Bottom-up law development through enabling models presents significant advantages not only to environmental law, but also other areas of the law.

Using the terminology just described, the "provision" and "enabling" models in many ways compare to what others simply call "bottom-up development" of the law. No matter what name is used for these models, they fill important gaps in relation to the role of law in urban environmental and human rights governance. National- and international-level action would still be highly advantageous to round out the picture of law development more homogeneously in both environmental and human rights law. It would also add significant law enforcement benefits. But until such scaled-up action is undertaken, local bottom-up action involving a multitude of actors including cities is key.

\section{B. Substantive Contents in Legal Developments}

The contents of the substantive provisions of new law is, of course, up to civil society and our lawmakers. This section will thus only highlight some generally applicable considerations that can be drawn from the above experiences.

First, as the Denver and Santa Fe examples show, it is important to consider the social and environmental justice implications of new legal provisions. In Denver, the African American community was affected when a construction project should and did bring about certain improvements of the area in question, but failed to take into account that the increasing price level resulting from this improvement would cause a shift in the racial make-up of the area. Human rights scholarship is ripe with examples of how poor environmentally related decisions may rise to the level of human rights violations. None of the above examples have presented problems of such magnitude, not even the Denver development. However, it is a sound approach to consider new action to be taken 
from a broad perspective including a broad range of social, economic, environmental and possible human rights consequences. Santa Fe did so with its focus on interweaving environmental stewardship with economic health and social justice. So did London by promoting "well-being" seen from a combined environmental, economic, and social point of view.

Attempting to take broad social implications into account when developing the law will raise the question of what "law" is to begin with. Considering this will help participants in the lawmaking process present arguments that the law has never just been a narrow range of cautious statutory or judge-made principles and should not be now either. Modern society is ill served by attempts to frame law so narrowly at a point in time when we need to broaden our conceptual understanding of what it takes to move forward in more socially expedient ways than perhaps ever before. Thus, as demonstrated, it is beneficial to consider the notion of law to be broad enough to also comprise ethical norms of what is "right" and what is "wrong." This will serve the environmental agenda well. The best law is that which features a great amount of intrinsic reasonableness and value seen from a broad, societal point of view. Social pressure can lead to just such norm-formation. Law is not merely traditional or "hard" law, but can - and should - contain elements of morality and general justice. Modernly, it is thus appropriate and expedient to consider law to comprise notions of "soft law" as well. This has the added advantage that civil society is equally or more likely to adhere to such law than strictly enforced, traditional-style mandates. As the discourse related to natural law further proves, modern legal developments should beand in fact often are-taken from not only an anthropological point in view, but also from an ecocentric point of view. If doing so, we take into account not only human beings and our needs, but also the inherent value we get from our non-human planetary co-inhabitants. For example, legal discourse relating to natural and human rights law already incorporates consideration of "life." One day, this might be legitimately expanded to cover non-human life as well. Laws already exist to protect threatened and endangered species, so this might not be a tremendous stretch of the legal imagination, as it may first appear. Similarly, our anthropological interest in, for example, aesthetic experiences, knowledge, and a clean, healthy environment by definition requires taking both animals and our other natural surroundings into account. Creating law from a broad perspective that, for example, incorporates the value of the natural environment for its own sake because it is simply the right thing to do is a more 
sustainable approach to legal developments than many current and more traditional legal approaches.

Substantive direction was, in San Francisco, influenced by international human rights treaty law. In New York, a local agency was created based on UN developments. Can an argument be made that sub-national action may also be modeled on international customary law or general principles of international law? Unfortunately not - at least, not yet. To do so would require pervasive and consistent national-level action taken out of a sense of legal obligation, but that is precisely the problem: national governments are often not taking substantively sufficient action when it comes to either environmental law or human rights law. Even when they do, the action taken is often too sporadic and new seen from an international point of view to classify as either customary law or general principles of international law. Accordingly, to emulate action on international law is arguably still best done by relying on treaty law. In this connection, it is important to remember that the demarcation between what was traditionally seen as "national" and "international" law is blurring. In some nations and contexts, even this line-blurring itself may not matter much. However, in the United States, attempts to mix national and international law may present significant sovereignty and federalism issues that will need to be addressed by law-and- policymakers. But it is important to bear in mind that whereas taking local action with some potential international implications may well present some difficult questions to be resolved, non-action in relation to issues of an international nature is even more problematic.

A note on cultural shifts and societal attitudes towards substantive legal provisions is in order in the context of which values different societies place on different norms and laws. For example, prevalent popular rhetoric indicates that many people tend to think that the EU is simply "different" when it comes to promoting both environmental sustainability and broad human rights issues. Thus, some may consider the attitude towards similar issues to be more or less unchangeable in the United States. But this would be a mistake, for although some basic values change rather slowly here, they do eventually do so. Consider, for example, the women's rights movement. Some may argue that this has not changed sufficiently yet, and for good reason. But there can be no doubt that women's rights in the United States have not changed dramatically for the better over a few decades. Similarly, a shift in the attitude towards environmental protection is noticeable in the United States, "even" among 
companies and "even" towards, for example, climate change. It is beyond the scope of this Article to analyze what causes such shifts in values. It is sufficient to point out here that social values do change over time, and with them, relevant laws must change substantively as well. Where the national and supranational regime may react too slowly or not at all, bottom-up polycentric action becomes highly relevant.

\section{Implementation}

Just as law is best initially developed through flexible, iterative processes, so should the implementation of new law be seen as an ongoing and flexible process. To make this as successful as possible, it has proved beneficial to measure progress against numerous benchmarks and to make adjustments along the way as necessary. Still, only $55 \%$ of the sustainability plans examined in one study created any implementation priorities. ${ }^{377}$ Authorities should make better use of such priorities, benchmarks, and other tools in prioritizing the action to be taken. The New York climate change model showed an example of a model that incorporates a large number of very specific benchmarks for a range of different government bodies. This promotes accountability and creates useful specificity for goal achievement purposes. San Francisco showed how monitoring and benchmark tools, such as the Gender Analysis Tool and Gender Responsive Budgeting, can be used in procedurally successful ways locally and promoted for international use even where the source for these initiatives was international law to begin with. Thus, "law" may initially stem from international inspiration, become localized, and then lead back up to the supranational scale.

Interdisciplinary and interagency approaches are called for in many areas of the law, but perhaps none so much so as climate change law. The current trend in the United States seems to be that authorities recognize this, but nonetheless limit such cooperation to their respective geographical regions. For example, Denver, Santa Fe, and New York City all indicate an interest in being seen as "leaders" within climate change and sustainability efforts (as do many other cities). Such competition may be seen as healthy, but research also shows that collaborative approaches present significant synergisms and economies of scale. It may prove very difficult or impossible to replicate these in a timely manner if most cities or regions continue to

377 Arnold, supra note 90, at 859. 
attempt to produce their own unique solutions to problems. There is no need to reinvent the wheel. Actors are well advised to actively seek out and encourage greater amounts of cooperation not only locally, but also regionally and internationally, for better substantive legal goals.

Of course, good law is all about good communication. And good law must, as shown, involve civil society stakeholders. How are these goals accomplished? Through public participation, but also through intelligent communication strategies. The Denver and London governance models exemplify today's key awareness of the importance of getting the message across to civil society in effective ways. Denver thus deliberately uses "social marketing" in an attempt to nudge civil society actors - both private and corporate - to change their behavior in the ways necessary for the City to reach its goals. London obtains consulting and communication assistance in relation to its London Plan from specialized private actors. Other localities should develop similar strategies.

\section{Enforcement}

What is law without enforcement and penalties, some may ask. Part of the answer is that law is not necessarily only observed because of external threats; intrinsic motivators and cooperative approaches are arguably just as effective in bringing about observance. This Article has operated with two major approaches to law enforcement: the traditional adversarial method (a "stick" model) and the more "carrot-like" cooperative method. Under the former, authorities can and will impose penalties and take other punitive or quasi-punitive action if legal mandates are violated. This adversarial-style approach is taken by the human rights regime in New York City. As the name indicates, the cooperative method is one in which collaboration between the overseeing authorities and the implementing actors is seen as key in reaching the objectives of the law in question. San Francisco uses this methodology in enforcing its human rights principles. What is better, an adversarial approach or a collaborative one? This question cannot be answered in full here or arguably anywhere, in part because it is difficult to trace substantive successes to any specific legal mandates and thus also to verify if any specific feedback loop on substantive failures work better than others. Nonetheless, research for this article shows that the collaborative approach is at least becoming more and more prevalent both in subnational law as well as in supranational instruments. Of course, 
traditional enforcement has its place in some contexts, such as in egregious cases of law violations and, arguably, where the law has deliberately been violated; but it is simply not true that for laws to be enforced, threats of penalties and other adversarial solutions always have to be applied. In several contexts, "softer" approaches such as assistance and cooperation has proved to be just as, if not more, beneficial. This is the case both in San Francisco, but also with international models such as those employed by the UNFCCC and the Aarhus Convention. Regardless of which model is used, enforcement functions should be located in separately dedicated bodies in order to avoid perverse incentives in withholding information from governments in order to not be penalized because of what that information reveals.

The above mainly relates to government bodies, but why does civil society observe the law? As with authoritative bodies, individuals do not only observe the law because of the threat of fines or other sanctions. We observe laws that we see as inherently good for us and expedient for our local environments. If laws are developed in procedurally sound ways, we tend to observe them, even if we do not agree with the substantive provisions. Procedurally sound law and policy development presents civil society with an opportunity to take a meaningful part in the decision-making process, including having an opportunity to present our views, to be heard, and to have our views considered by the authorities. Just as it is important to incorporate public participation provisions in the creation of laws, so can it be beneficial to incorporate civil society in law enforcement to the extent feasible seen from a practical point of view. ${ }^{378}$ Finally, people tend to be more willing to observe laws created by "competent" governments - in other words, those that are seen as impartial and just. Authorities are beginning to take note of the importance of public participation. For example, one study shows that $85 \%$ of a select range of local sustainability plans included policies for public awareness, participation, and education. ${ }^{379}$

What emerges from this is the fact that to create new solutions to pressing legal issues, we should develop new solutions to law enforcement as well as to law creation. Importantly, we should dare to

378 See the author's analysis of this in Marianne Dellinger, Ten Years of the Aarhus Convention: How Procedural Democracy is Paving the Way for Substantive Change in National and International Environmental Law, 23 COLO. J. INT'L ENVTL. L. \& POL'Y 309 (2012).

379 Arnold, supra note 90, at 858. 
move away from yesterday's traditional, adversarial approaches that may at one level be efficient, but at another may create more hostility and resentment of government bodies than what is desirable. Instead, just as governments are more and more often expected or even required to collaborate with an increasingly broad range of other government agencies and civil society actors, so should such cooperation and the hopefully resulting innovations of legal schemes be enforced in cooperative ways. This model is emerging as an efficient way of reaching the desired ultimate substantive goals. Authorities would be well advised to consider this approach. Similarly, public involvement at all stages of law creation and enforcement is also a recognized boon to society in general. Authorities should learn from this development and implement greater amounts of involvement by civil society organizations as the true stakeholders of the action to be taken.

\section{CONCLUSION}

This Article demonstrated how bottom-up, polycentric, collaborative approaches to lawmaking and -enforcement present relatively untraditional, yet effective, inroads to progress in both human rights and environmental law on the national and international scales. The Article argued that although "law" is often understood to be law formally adopted by governments, the concept is broad enough to also encompass moral and ethical aspects. Such "softer" notions of law are important to the legal discourse within both human rights and environmental law. Further, because civil society tends to more readily adhere to mandates that are seen as inherently "good" and beneficial to society at large than more narrowly framed, top-down negative notions of what cannot be done, framing new legal mandates from a positive and aspirational angle is beneficial. Similarly, drawing on non-Western ideals as well as ancient notions of natural law has the potential of creating more equitable solutions seen from both an ecocentric and anthropological angle.

The Article also demonstrated the modernly recognized importance of public participation to norm-formation and formal lawmaking. New solutions incorporating civil society stakeholders as well as multi-level governance units have proven to be not only viable and effective both procedurally and substantively. Even if bottom-up, collaborative approaches to lawmaking do not initially lead to the adoption of formal law, they have been demonstrated to lead to the creation of social norms that over time will fossilize into formal law. 
And just as collaborative solutions are an advantage in connection with the creation of law, so do the experiments analyzed above show that collaboration in law enforcement may be an equally or more effective than traditional, adversarial law enforcement.

In short, new directions within the fields of human rights and environmental law must involve multi-stakeholder, multi-level action for more progressive solutions within shorter time-frames than what is often the case with traditional large-scale, top-down approaches. The time has come to take action on multiple fronts and to apply a multitude of approaches and policy instruments to make much needed progress. Now as never before, we need "all hands on deck" to handle persistent and urgent socio-legal problems both within and beyond human rights and the environment. 